\title{
MULTISTATE ACCOUNTS RECEIVABLE FINANCING: CONFLICTS IN CONTEXT
}

Characterized by contacts in many states with diverse laws, assignments of accounts receivable give rise to exaggerated conflict of laws problems. Accounts receivable financing enables businesses to meet continuing demands for operating capital. ${ }^{1}$ Sales of accounts, involved in old-line factoring, have long been employed in the textile and related industries. ${ }^{2}$ Under this method of financing, accounts receivable are assigned to and discounted by factors who usually notify account debtors of the arrangement and collect the accounts. ${ }^{3}$ Sellers of accounts guaranty only authenticity of debts; factors assume the risk of noncollection. ${ }^{4}$ In modern receivables financing, on the other hand, assignee banks or finance companies do not notify account debtors or collect receivables $;^{5}$ and they retain recourse against assignors in case of default by

1. An account receivable may be defined as an indebtedness for services or merchandise furnished, not evidenced by any formal written acknowledgment executed by the debtor. Boas, Legal and Economic Aspects of Accounts Receizable Financing and Factoring, 59 Cons. L.J. 65 (1954).

"[T] been served primarily by various forms of both inventory and accounts receivable financing." Greenberg, Inventory and Accounts Receivable Financing, 1956 U. IL.L. L. FoRUMI 601. Such financing is used primarily by small business for which unsecured credit is unavailable. Kupfer, Accounts Receivable Financing: A Legal and Practical Look-Sec (Part 1), The Practical Lawyer, Nov. 1956, p. 50. The receivables arrangement has the characteristics of both short and long-term loans: short-term to the extent that the collateral automatically extinguishes the obligation, see text at notes 11,12 infra, and longterm in the sense that a constant arrangement through the medium of revolving funds is contemplated. Boas, supra.

2. Phelps, Accounts Recervable Financing as a Method of Business Finance 12 (Commerctal Credit Company, Studies in Commercial Financing, No. 2, 1957); Silverman, Factoring as a Financing Device, 27 HARv. Bus. REv. 594, 597-98 (1949); Business Week, Jan. 11, 1958, p. 84.

3. Ordinarily, the factor also relieves his client of the functions of credit investigations and accounts receivable bookkeeping. PhelPs, op. cit. supra note 2, at 12; Koessler, Assignments of Accounts Receivable, 33 CALIF. L. Rev. 40, 54 (1945); Silverman, supra note 2 , at 596, 599; Business Week, Jan. 11, 1958, p. 86 . The factor protects himself by approving accounts and checking prospective account debtors. Id. p. 84. The fee charged for the risks and services of collection usually ranges between $1-1 \% 2 \%$. When many small accounts must be collected, fees may reach $2 \%$; when collection is simple, they may be as low as $3 / 4 \%$. Id. p. 86 . To facilitate credit investigations in nonrecourse financing, factors have built up comprehensive credit files for the textile industry. The great cost of this has, of course, been spread over the great number of accounts. But the necessity of developing new files before entering new fields limits possibilities of expanding old-line factoring. Silverman, supra note 2 , at $598-99$.

4. Phelps, op. cit. supra note 2, at 12; Lowenstein, Assignments of Aicounts Riceivable and the Bankruptcy Act, 1. RUTGers L. Rev. 1, 6-7 (1947).

5. "Before the depression of the 1930's, banks did not often venture into the field of lending on borrowers' accounts receivable ... because of the added expenses and trouble 
account debtors. ${ }^{6}$ Designed more as a security device than a sale, the modern transaction is typically governed by a basic contract to assign or "sell" existing and future accounts in exchange for continuing credit. ${ }^{7}$ The borrower agrees not to assign to another concern, and the lender is free to notify account debtors at any time as well as to refuse advances on the basis of precarious

involved. Nevertheless, seeking for profitable loan outlets, the banks have gradually moved into this field that previously was the special province of the finance companies." THomas, Our Modern Banking and Monetary System 165-66 (3d ed. 1957). Modern receivables financing is handled primarily by finance companies and commercial banks, with factors-mainly the large and few "Fourth Avenue Houses"-concentrating on nonrecourse financing. Koessler, supra note 3, at 52-56; Lowenstein, supra note 4, at 6-7.

6. Since in modern accounts receivable financing arrangements the borrower operates his own credit department, does his own bookkeeping and collects the accounts, the lender does not have the day by day control over credits and collections characteristic of old-line factoring. Hence, advances in nonnotification financing are usually made with recourse. Phelps, op. cit. supra note 2 , at 16 . But nonnotification financing need not always be coupled with a right of recourse. Thus, some finance companies are beginning to take accounts either entirely without recourse or with limited liability on the part of the assignor for credit losses. Id. at 61 ; Kupfer, supra note 1, p. 55; Drake, Outlook for Commercial Finance Companies and Factors for 1956, The Commercial and Financial Chronicle, March 8, 1956, p. 6.

Notification financing is in some ways preferable to nonnotification arrangements. The assignee need not rely on the borrower to forward all remittances or in general to comply with the strictures of Benedict v. Ratner, 268 U.S. 353 (1925), note 17 infra. Once notified of the arrangement, an account debtor pays the assignor at his peril. See note 46 infra. For this very reason, however, the plan is unacceptable to many potential borrowers who prefer to maintain direct relationships with customers. In addition, assignors fear that customers burdened with the necessity of determining the payee of remittances might look elsewhere for their business. See Boas, supra note 1 , at 59-60. On the other hand, the interest rate for accounts receivable financing is almost twice that charged by Id-line factors, i.e., about $12 \%$ as against 6-7\%. Business Week, Jan. 11, 1958, p. 86.

7. " $[\mathrm{F}]$ inance companies generally use the technique of purchasing open accounts, while many commercial banks follow the procedure of lending on the security of a pledge - $f$ such receivables. [Usually because they lack either express or implied statutory power ' purchase accounts receivable. Denowi, Secured Transactions 60 (1955).] In both - ises the advances are made with recourse to the customer for credit losses and without -otice to his trade debtors." Prelps, op. cit. supra note 2, at 16; Note, 101 U. PA. L. Rev. "72 (1952). Whatever label is given to the transaction by the parties, it seems meaningless to call a modern receivables financing arrangement a sale as long as the assignee is guaranteed full recovery of the debt plus charges from the assignor. One reason for the practice may be to escape usury statutes which apply to loans but not to sales and thus permit any discount in a sale. Yet in Milana v. Credit Discount Co., 27 Cal. $2 d$ 335, 163 P.2d $\$ 69$ (1945), when a purported sale was rescindable by the assignee after the account debtor's default, the court held that for usury purposes the label need not control and remanded the case for determination of whether the usury statute applied. Cf. In re $\mathrm{L}$. Gandolfi \& Co., 113 F.2d 300 (2d Cir. 1940) ("while the agreement took the form of a contract of sale, it is tolerably clear that the arrangement was in reality one for loans on the security of assigned accounts"; nonusury context). But cf. In re Mesibovsky, 200 Fed. 562 (2d Cir. 1912) ; Spain v. Talcott, 165 App. Div. 815, 152 N.Y. Supp. 611 (1st Dep't 1915). 
accounts. ${ }^{8}$ Pursuant to the agreement, the assignor periodically delivers schedules of accounts to the assignee and receives an agreed percentage of their sum. ${ }^{9}$ Differentials between security and loans afford safety margins against noncollection, insolvency and dishonesty. ${ }^{10}$ As the assignor collects receivables and remits proceeds, he delivers new schedules of accounts and acquires from the assignee further advances in the same ratio. ${ }^{11}$ Thus, payment comes automatically from the security, and the proportion of loans outstanding to accounts assigned generally remains constant. ${ }^{12}$

Since the second World War, accounts receivable financing has experienced accelerated growth. The business community formerly regarded assignments of accounts receivable as distress measures portending insolvency. ${ }^{13}$ Commercial disparagement was substantially allayed, however, by the increasing practice, authorized by the Federal Assignment of Claims Act, of assigning defense contracts. ${ }^{14}$ Moreover, with unprecedented business growth, rising taxes and inflation heightening pressures on working capital, businessmen realized the necessity of augmenting credit resources by hypothecating or selling accounts. ${ }^{15}$ Thus impelled, accounts receivable financing attained commercial recognition as a respectable method of securing revolving credit. ${ }^{16}$

8. Note, 101. U. PA. L. Rev. 392, 393 (1952). But see Koessler, supra note 3, at 56, stating that nonnotification agreements generally provide for no notification except in extraordinary contingencies, such as the assignor's insolvency.

Receivables financing agreements usually contain acceleration clauses operative at the will of the assignee or when he feels insecure. The UNIFORM COMMIRRCIAL CODE $\$ 1-208$ and the majority rule hold that the assignee may accelerate only if he believes in good faith that the prospect of payment is impaired. Kupfer, Assignments of Accounts Receivable: A Legal and Practical Look-See (Part 2), The Practical Lawyer, Dec. 1956, pp. 55, 64.

9. Delivery is often made daily. New York LAw Revision Conrusssion, Assignarents of Accounts Recervable 285 (1946). Percentages vary from 70-95\% of the face value of the assigned accounts. PHelps, op. cit. supra note 2 , at 38 .

10. See Note, 101 U. PA. L. Rev. 392-93 (1952).

11. See note 29 infra for further discussion of such financing arrangements.

12. Note, 101 U. PA. L. Rev. 392, 394 (1952). The "automatic payment" feature keynotes the desirability of receivables security. Unless many accounts prove worthless, defaults cannot occur and costly foreclosure proceedings are unnecessary. See Note, 66 YALE L.J. 257 (1956).

13. See New York Law Revision Conrmission, op. cit. supra note 9, at 6; Phelps, op. cit. supra note 2, at 16-17, 63. Even today, a creditor sometimes takes assignments as further security from a sinking debtor. But this is the exception rather than the rule. Koessler, supra note 3 , at 59.

14. 54 Stat. 1029 (1940), as amended, 31 U.S.C. $\$ 203,41$ U.S.C. $\$ 15$ (1952). See Phelps, op. cit. supra note 2 , at 61 ; Lowenstein, supra note 4 , at 2 .

15. Phelps, op. cit. supra note 2, at 58-59. The reason for increased use of receivables financing in the last few years has been stated as (1) the growing corporate need for liquid capital and (2) the difficulty of obtaining bank loans under the tight money conditions prevalent since 1952. Business Week, Jan. 11, 1958, p. 84.

16. " $[F]$ ar from being a 'symptom of financial distress,' this sort of loan has become the stepping stone on which a borrower can lift himself to a sounder position." Loans on Acconnts Receivable, 55 U.S. InvesToR 1985, 2023 (1944). See also Reese, Highlights 
But expanding usage also resulted in multistate transactions and, consequently, exposure to divergent state laws.

Disparate state treatment stems largely from the rule of Benedict $v$. Ratner, which requires borrowers to account to lenders for the proceeds of assigned receivables. ${ }^{17}$ Benedict invalidates nonnotification assignments when an assignor's retention of proceeds is expressly permitted or the assignee's consent may be implied from his failure to demand prompt remission of-police-collected amounts. ${ }^{18}$ Thus, absent substitution of new accounts, a borrower who does

From the Southern Consumer Credit Clinic, Credit Currents, Feb. 1952, p. 25; ScHulrz \& Reingardi, Credti and Collection Managenient 568 (2d ed. 1954). The volume of nonnotification financing done by finance companies and factors rose from $\$ 536$ million in 1941 to $\$ 5.6$ billion in 1956. Saulnier \& Jacoby, Accounts Receivable Financing 36 (1943) ; Drake, The Comnitercial Finance Industry's Trade Group, in Natronal CoMmerctal Finance Conference, Inc., Twelfth Annual Convention of the Commercial Finance Industry 5 (1956). The combined total of factoring and loans against receivables in 1957 is estimated at $\$ 11$ billion, $2 \frac{1}{2}$ times that of 1946 . Business Week, Jan. 11, 1958, p. 84. Modern receivabies financing comprises $\$ 6.5$ billion, old-line factoring $\$ 4.5$ billion. Id. p. 86 . Although mostly small and medium sized firms make use of accounts receivable financing, large firms as well are increasingly employing this security device. PHELPS, op. cit. supra note 2 , at 62 .

17. 268 U.S. 353 (1925). Benedict, a judicially imposed rule obtaining in many states, see Annot., 85 A.L.R. 222 (1933); Note, 24 N.Y.U.L.Q. Rev. 598 (1949); Note, 101 U. PA. L. REv. 392 (1952), requires that the lender "police" his loans on pain of losing all his collateral under a fraud-in-law doctrine. The borrower must turn over to the lender all proceeds of assigned accounts as he receives them or at regular intervals, usually by endorsing checks and placing them in an account upon which he cannot draw. In addition, the assignee must set up rather elaborate machinery to check the borrower's actions. Dunham, Invantory and Accontsts Receivable Financing, 62 HARv. L. Rev. 588, 593 (1949). He ordinarily takes monthly audits of the assignor's books and operations and periodically makes spot checks by way of direct correspondence between the auditing concern and account debtors selected at random. Kupfer, Accounts Receivable Financing: $A$ Legal and Practical Look-See (Part 1), The Practical Lawyer, Nov. 1956, pp. 50, 55. For further discussion of practices which have and have not been allowed, see NEW YORK LAW REvision Connmssion, op. cit. supra note 9, at 142-46; Note, 24 N.Y.U.L.Q. Rev. 598, 60003 (1949). For the possible effect of the Uniform Frandulent Conveyance Act on this doctrine, see Cohen \& Gerber, Mortgages of Accounts Receizable, 29 GEo. L.J. 555, 571 (1941).

Bencdict v. Ratuer has been widely criticized. See, e.g., Lowenstein, supra note 4, at 13-14; Note, 101 U. PA. L. Rev. 392, 400 (1952). Yet the finance companies themselves do not urge abolition of the rule. Its requirements represent minimal standards which responsible lenders observe absent Benedict to prevent dissipation of collateral and "kiting" of assignments. Id. at 401. Existence of the doctrine as a legal requirement thus facilitates imposing the necessary practices on borrowers who may otherwise feel that they are being distrusted. See Nattonal Conference of Commerctal Receivable Companies, Inc., Ergrth Annual Convention of the Commercial Finance Industry 170-74 (1952); cf. Malcolm, Explanation and Analysis of Massachusetts Honse Bill No. 642, Mass. L.Q., Oct. 1945, pp. 26, 37. Another and perhaps equally important reason may be that the finance companies feel they have acquired a skill in navigating among the shoals of Benedict, removal of which would invite other commercial lenders to enter the receivables financing waters.

18. Contracts satisfying Benedict will not save an assignment if, in practice, the as- 
not segregate returned merchandise or who makes price adjustments altering the amounts due from account debtors will jeopardize his assignee's security interest in all accounts. ${ }^{19}$ Several courts have refused to adopt Benedict ${ }^{20}$ others may endorse the rule generally with respect to retention of proceeds but reject its stricter applications to returned goods and price adjustments. ${ }^{21}$ Even in those states which adhere to the full scope of the Benedict doctrine, dominion over proceeds does not preclude validity if the assignor substitutes receivables of equal value for the dissipated security. ${ }^{22}$

In addition to Benedict, common-law rules regarding assignment of future accounts and priority between assignees of the same account may impair an assignee's security interest. Assignments of debts to arise in the future are often held ineffective as against garnishing creditors or subsequent assignees unless perfected, upon creation of the accounts, by further acts of assignment. ${ }^{23}$

signee permits violations of the rule. Lee v. State Bank \& Trust Co., 38 F.2d 45 (2d Cir. 1930).

19. The rationale for extending Benedict is that dominion over returned goods or the right to make price adjustments is tantamount to dominion over proceeds. See, e.g., Lee v. State Bank \& Trust Co., 54 F.2d 518 (2d Cir. 1931) (returned goods amounted to less than $1 \mathrm{I} / 4 \%$ of the assigned accounts, yet assignment held invalid) ; Zydney v. New York Credit Men's Ass'n, 1.13 F.2d 986 (2d Cir. 1940) (returned goods) ; Peterson v. National Discount Corp., 179 Wash. 108, 35 P.2d 1097 (1934) (credits and adjustment). Once the security interest in part of the accounts is thus invalidated, the entire assignment may fail under the "part bad-all bad" rule of Brown v. Leo, 12 F.2d 350 (2d Cir. 1926). But see In re Hanover Milling Co., 31 F.2d 442 (D. Minn. 1929). Courts vary in determining the permissible degree of dominion over returned goods. See, e.g., In re L. Gandolfi \& Co., 113 F.2d 300 (2d Cir. 1940) (basic agreement required assignor periodically to deliver lists of returned goods; returned goods were not segregated and assignor was lax in reporting returns; assignments nevertheless upheld) ; Bloch v. Mill Factors Corp., 134 F.2d 562 (2d Cir. 1943) (to invalidate assignment, assignee must have known of and agreed to resale of returned merchandise by assignor for own benefit). For statutory changes of this rule, see note 45 infra.

20. See, e.g., In re United Fuel \& Supply Co., 250 Mich. 325, 230 N.W. 164 (1930); cf. In re Robert Jenkins Corp., 17 F.2d 555 (1st Cir. 1927).

21. This approach is suggested by the accounts receivable statutes passed in recent years, which have rejected only Benedict's application to returned goods and adjustments. See note 45 infra.

22. Mr. Justice Brandeis, in Benedict v. Ratner, 268 U.S. at $364 \mathrm{n} .18$, suggested that the result would have been different if the underlying agreement, while permitting the assignor to collect the assigned accounts, had required him to substitute other accounts of equal value. Accord, Clark v. Iselin, 88 U.S. (21 Wall.) 360 (1874) ; Second Nat'l Bank v. Phillips, 189 F.2d 115 (5th Cir. 1951). See also Lowenstein, supra note 4, at 9-11; Notes, 24 N.Y.U.L.Q. Rev. 598, 601 (1949), 101 U. PA. L. Rev. 392, 395-96 (1952). But factors are wary of using substitution and rarely resort to this device. Id. at 394.

23. Courts often reason that an assignee of accounts to arise in the future obtains mere equitable title which is subordinate to the legal title later acquired by other assignees or attaching creditors. State Factors Corp. v. Sales Factors Corp., 257 App. Div. 101, 12 N.Y.S.2d 12 (1st Dep't 1939). New York law, however, is unclear. See NEw YoRk LAw Revision Commission, Assignments of Accounts Receivable 56-59, 94-104 (1946). See also Taylor v. Barton Child Co., 228 Mass. 126, 117 N.E. 43 (1917) ; First Nat'l Bank 
"Automatic perfection" doctrines, endorsed in other states, permit contracts assigning future accounts to encumber receivables as they come into existence. ${ }^{24}$ Similarly, opposing views prevail with respect to priority of liens asserted in the same accounts by two good-faith assignees. The majority, or American, rule accords priority to liens established first in time, ${ }^{25}$ while the minority, English, doctrine favors the claims of assignees who first notify account debtors. ${ }^{26}$

v. Campbell, 193 S.W. 197 (Tex. Civ. App. 1917). Nevertheless, debts to become due under an existing contract are assignable in most jurisdictions. See Restatenrent, CoNTRACTS § 154 (1932).

In ordinary receivables arrangements, the periodic delivery of schedules of new accounts constitutes the further act required. Precedent in some states holds the date of perfection to relate back to the original assignment. Of little utility outside of bankruptcy, relationback doctrines have been rendered unavailing by amendments to the Bankruptcy Act. NEW YoRk LAw Revision CoMrMission, op. cit. supra at 90-93.

24. E.g., Union Trust Co. v. Bulkeley, 150 Fed. 510 (6th Cir. 1907) (Michigan law); Baskin v. Aetna Life Ins. Co., 190 Ark. 448, 79 S.W.2d 724 (1935) ; Girard Trust Co. v. Standard Gas Co., 93 N.J. Eq. 307, 115 Atl. 910 (Ch. 1921). But cf. Stokely Bros. \& Co. v. Conklin, 131 N.J. Eq. 552 (Ch. 1942) (apparently requiring that the account have a potential existence). This is also the English rule. See In re Lind, [1915] 2 Ch. 345 ; Annot., 72 A.L.R. 856 (1931). For an exhaustive discussion of this problem, see NEw YoRK LAw Revision Commission, op. cit. supra note 23, at 44-104. For statutory changes of the common law in this field, see note $44 \mathrm{infra}$. A discussion of the desirability of the floating lien appears in New York Law Revision Commission, Study of Uniformi Commercial Code, Article Nine 135-95 (1955).

25. The American rule, formerly in the minority, gained currency through the years. See Annot, 110 A.L.R. 774 (1937) ; Koessler, supra note 3, at 63-64. For a listing of states presently adhering to the rule, either by court decision or by statute, see note 32 infra. Two versions, the New York and Massachusetts rules, obtain. The former recognizes no exception to the proposition that the first assignment in time prevails, Superior Brassiere Co. v. Zimetbaum, 214 App. Div. 525, 212 N.Y. Supp. 473 (1st Dep't 1925), while the Massachusetts rule holds that a second assignee who without knowledge of a previous assignment collects debts from account debtors may retain the proceeds, Rabinowitz v. People's Nat'l Bank, 235 Mass. 102, 126 N.E. 289 (1920). The Restatement of Contracts elaborated the Massachusetts rule into the "four horsemen" doctrine, which lists three other circumstances under which a subsequent good-faith assignee for value may prevail: (1) by obtaining a judgment against the original obligor (account debtor) ; (2) by entering into a new contract with the obligor by way of novation; (3) by obtaining delivery of a token in writing, surrender of which is necessary for the enforcement of the obligor's debt. Restatenient, Contracts $\$ 173$ (b) (1932). For the origin of these exceptions, see Lowenstein, supra note 4, at 19.

26. A few jurisdictions still adhere to the English rule, which received its name from the case of Dearle v. Hall, 3 Russ. 1, 38 Eng. Rep. 475 (Ch. 1828). See, e.g., Wade v. Security Sav. \& Commercial Bank, 69 App. D.C. 226, 99 F.2d 995 (1938) ; Canton Exchange Bank v. Yazoo County, 144 Miss. 579, 602, 109 So. 1, 4 (1926) ; Moran v. Adkerson, 168 Tenn. 372, 79 S.W.2d 44 (1935). For a list of other states which followed this rule until accounts receivable statutes, notes 32,33 infra, were enacted, see Koessler, supra note 3 , at 70 n.105. The majority of these states required notification only as against a competing assignee not an attaching creditor on the theory that the latter acquired no better rights than the assignor had. Conwill \& Ellis, Much Ado About Nothing: The Real Effect of Amended 60(a) on Accounts Receivable Financing, 64 HARv. L. Rev. 62, 65 (1950). 
After enactment of the Chandler Act, the choice between the two rules became critical. ${ }^{27}$ Section sixty made certain assignments preferential and voidable if subsequent bona fide assignees could obtain superior liens within four months of bankruptcy. ${ }^{28}$ Since subsequent assignees could always prevail, nonnotification financing arrangements governed by the English rule were rendered vulnerable to invalidation. ${ }^{29}$

27. Chandler Act of June 22,1938 , c. 575,52 Stat. 840 (codified, as amended, in scattered sections of 11 U.S.C.).

28. 52 Stat. 869 (1938) (amended by 64 Stat. 24 (1950), 11 U.S.C. $\$ 96$ (1952)).

29. In the much publicized case of Corn Exchange Nat'l Bank \& Trust Co. v. Klauder, 318 U.S. 434 (1943), the Court invalidated a nonnotification assignment executed in Pennsylvania, then an English rule state. To reach this conclusion under $\$ 60$, the Court had to find that, among other things, the transfer was made for an antecedent debt and within four months of bankruptcy. 52 STAT. 869 (1938), 11 U.S.C. $\S 96$ (1952). Although the assignment was, in fact, effected concurrently with the loan (less than four months before bankruptcy) the Court deemed the transfer made at the time of bankruptcy, and thus on account of an antecedent debt. For $\$ 60$ provided that a transfer "shall be deemed to have been made at the time when it became so far perfected that no bona-fide purchaser from the debtor and no creditor could thereafter have acquired any rights in the property so transferred superior to the rights of the transferee therein." 52 STAT. 869 (1938) (amended by 64 Stat. 24 (1950), 11 U.S.C. $\$ 96$ (1952)). And a subsequent assignee in an English rule state, reasoned the Court, could have acquired rights superior to those of the lender by giving the account debtor notice of the assignment.

In In re Vardaman Shoe Co., 52 F. Supp. 562 (E.D. Mo. 1943), a district court held that, even under the Massachusetts version of the American rule, an assignment similar to that in Klauder was invalid under $\$ 60$, since, according to the four horsemen exception, a subsequent good-faith assignee could prevail by, e.g., collecting proceeds or obtaining a judgment against the account debtor. See note 25 sttpra. Vardaman was severely criticized by commentators, e.g., Koessler, supra note 3, at 85, and courts, e.g., In re Rosen, 157 F.2d 997 (3d Cir. 1946), cert. denied, 330 U.S. 835 (1947). With state statutory elimination of the four horsemen, the Vardaman problem became moot until Kansas incorporated one of the horsemen in its recording act. Finally, $\{5$ of $\$ 60$ (a) of the Bankruptcy Act as amended in 1950, 64 STAт. 25 (1950), 11. U.S.C. $\S 96(a)$ (5) (1952), rejected the Vardaman result by providing that transfers actually made for present consideration cannot be deemed unperfected merely because other lien creditors might have prevailed through acts "which require the agreement or concurrence of any third party"-for example, by satisfying one of the four horsemen conditions. See H.R. REP. No. 1293, 81st Cong., 1st Sess. 5 (1949). Gearing the time of perfection to a judicial lien creditor test, rather than the former bona fide purchaser rule, the amendment also substantially protected assignments from English rule vulnerability. See note 26 supra. But, since most states had enacted statutes rejecting the English rule by 1950, this effect was negligible. Conwill \& Ellis, supra note 26, at 76-78.

The ordinary receivables financing arrangement may appear at first glance very much like a single loan of a given sum made at the beginning of the arrangement and secured by new collateral as the old collateral expires. To guard against a $\$ 60$ attack on the ground that all collateral assigned within four months of bankruptcy was given for an antecedent debt, the arrangement should follow the outline shown in text at notes 8-12 supra. Thus, as proceeds come in, the loan is paid off-legally and for accounting purposes. Simultaneously, new accounts are assigned for new consideration, i.e., the extension of new credit, although from the assignor's point of view, the receipt of such new credit is roughly equivalent to receiving the proceeds of old accounts, and, in fact, the agreement may be couched 
The thirty-seven state statutes ${ }^{30}$ passed to obviate this result amplify dis-

in terms of releasing the old collateral in return for new accounts. These arrangements are upheld as creating no preference if the release is made at the same time or shortly after the new assignments. Lowenstein, supra note 4 , at 9 . However, viewing the revolving credit arrangement as a series of individual transactions may give rise to a problem. In Wolf v. Aero Factors Corp., 126 F. Supp. 872 (S.D.N.Y. 1954), aff'd, 221 F.2d 291 (2d Cir. 1955), some groups of accounts assigned within four months of bankruptcy proved collectible, others not; the trustee argued that the credit extended at any one time was secured only by the accounts assigned at that time and by no others, so that part of the loan was unsecured even though the total amount of credit was less than the total amount of outstanding and collectible collateral. The court rejected this reasoning and held that the accounts were assigned and credit extended pursuant to the terms of the factoring agreement which provided that the assignee could apply excess collateral to any indebtedness then or thereafter becoming due from the bankrupt. Since none of the assignments were preferential, except in so far as some collateral was applied to antecedent indebtedness rather than present or subsequent debts, and since they were made as part of a single agreement, the assignee could set off the credit extended on the worthless accounts against the excess of the other collateral under the "mutual debts or mutual credits" rule of $\$ 68$ of the Bankruptcy Act, 52 Stat. 878 (1938), 11 U.S.C. $\$ 108$ (1952).

But, considering the arrangement a series of individual transactions, a court could hold assignments preferences to the extent they exceed advances made simultaneously and rule that under $\$ 60$ (c) of the Bankruptcy Act, 52 STat. 870 (1938), 11 U.S.C. $\$ 96(c)$ (1952), later advances may be set off against preferential transfers only if such advances were made "without security of any kind."

30. See notes 32, 33 infra. This Comment will not consider the conflicts problems raised by factors' lien recording acts. Most of these acts permit the financing parties to obtain liens both on inventory and accounts arising from the sale of inventory subject to liens. Note, 101. U. PA. L. Rev. 392, 398 (1952). Although substantively related to accounts receivable financing, factors' liens present distinct conflicts problems because tangible property as well as accounts are involved in the security arrangement. Unlike conflicts rules regarding receivables financing, the doctrine governing transfers of chattel interests-lex situs-almost universally prevails. See LaLive, The Transfer of ChatTels in the Conflict of Laws $48-59$ (1955) ; Zaphiriou, Transfer of Chatrels in Private InternaTIONAL LAw 74-75 (1956). But see Note, 66 YALE L.J. 567 (1957), advocating lex loci commserciendi for trust receipt problems arising in bankruptcy. And to preserve the utility of these statutes, factors' liens encumbrancing accounts upon sale of liened inventory should be governed by the same conflicts rule which pertains to the charged merchandise. Accordingly, the only factors' lien statutes relevant to this Comment are those embracing accounts receivable which need not arise from the sale of liened inventory. However, the New York and New Jersey statutes, which contain such provisions with respect to after-acquired accounts, are conditioned on notification of account debtors. N.J. STAT. A.NN. $§ 2 A: 44-183$ (Supp. 1957) ; N.Y. Pers. Prop. LAw $§ 45$. Assignees are unlikely to permit the validity of security to hinge on assignors' conscientious notification. Moreover, assignors most likely prefer delivering schedules of new accounts to notifying their customers. Thus, receivables financers in these states probably ignore the factors' lien statutes and conform assignments to common-law standards.

The only factors' lien act which seems effectively adaptable to pure accounts receivable operations and therefore within the scope of this Comment is the New Hampshire statute. N.H. Rev. Stat. ANN. §§ 446:1-:10 (Supp. 1957) ; see note 44 infra.

The possibility that assignments can be upheld when they satisfy a chattel mortgage filing statute, despite noncompliance with an accounts receivable filing act, was recognized in In re Steele, 122 F. Supp. 948 (E.D.N.C. 1954). Applicability of chattel mortgage 
parities among state substantive laws. ${ }^{31}$ Validation statutes codify the American rule simply by repudiating notification requirements. ${ }^{32}$ Recording statutes achieve the same effect by substituting general notice filing for assignees' notifcation of account debtors. ${ }^{33}$ While the two principal types of legislation thus

statutes, while increasing diversity of state law, would not alter the policy considerations involved in choosing a conflicts rule for receivables assignments.

31. The Fifth Circuit took judicial notice that the Chandler amendment of $\$ 60$ prompted enactment of the Florida act. M. M. Landy, Inc. v. Nicholas, 221 F.2d 923, 92728 n.4 (5th Cir. 1955); accord, Costello v. Bank of America, 141 F. Supp. 225, 227-29 (N.D. Cal. 1956). See also Koessler, supra note 3, at 50.

32. Validation statutes enact the New York version which upholds assignments first in time irrespective of any action taken by subsequent assignees. See note 25 supra. Such statutes are in effect in fourteen states: ARK. Stat. Ann. $\$ 68-805$ (Supp. 1955); Conn. Gen. Star. $\$ \$ 6718-26$ (Supp. 1955) ; Ill. Ann. Stat. c. 1211/2, $\$ \$ 220-22$ (Smith-Hurd Supp. 1957) ; Ind. Ann. Stat. \$\$ 19-2101 to -2104 (Supp. 1955); Me. Rev. Stat. Ann. c.

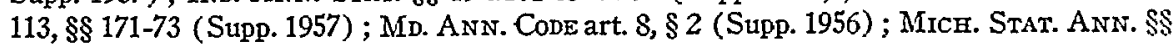
19.841-.851 (Supp. 1955) ; MrNn. Stat. Ann. \$\$ 521.01-.07 (Supp. 1957) ; N.H. Rev. Stat. ANN. \$\$ 333:1-:7 (Supp. 1957) ; Ore. Rev. Stat. $\$ 80.010$ (1955) ; R.I. Acts 1943, c. 1345, $\$ \S 1-2$; S.D. CoDE $\$ 51.0803$ (Supp. 1952); VA. CODE ANN. $\$ \$ 11-5$ to -7 (1956); Wis. STAT. \& 241.28 (1955).

In contrast with filing statutes, see note 33 infra, validation acts are generally short. Besides affirming the priority of the assignee first in time, they preserve to account debtors the right of discharge upon good-faith payment to someone other than the assignee.

Massachusetts, where a validation statute was passed in 1945, Mass. Ann. Laws c. 107A, \$\$ 1-6 (Supp. 1957), recently enacted the Uniform Commercial Code, effective Oct. 1, 1958, Mass. Acts 1957, c. 765, Mass. L.Q., Oct. 1957, p. 22, and must now be classed among the recordation states. See note 33 infra.

Four states adhere to the nonnotification rule by court decision. Columbia Finance \& Trust Co. v. First Nat'1 Bank, 116 Ky. 364, 76 S.W. 156 (1903) ; Moorestown Trust Co. v. Buzby, 109 N.J. Eq. 409, 157 Atl. 663 (Ch. 1931) ; McKenzie v. Irving Trust Co., 266 App. Div. 599, 42 N.Y.S.2d 551. (1st Dep't-1943), reaffirming the leading case of Fortunato v. Patten, 147 N.Y. 277,41 N.E. 572 (1895) ; Fidelity Mut. Life Ins. Co. v. City Nat'1 Bank, 95 F. Supp. 276 (N.D.W. Va. 1950). Montana courts also seem to follow the doctrine. General Elec. Co. v. Black, 19 Mont. 110, 47 Pac. 639 (1897).

On possible application of factors' lien recording acts to accounts receivable financing in certain validation states, see notes 30 supra, 45 infra.

33. Filing statements usually require no more information than the names of the assignee and assignor, plus their intention to conduct receivables financing. Compare UNIFORM TRUST RECEIPTS ACT $\$ 13$. Twenty-two states now have such statutes: ArA. CODE tit. 39, $\$ \S 207-14$ (Supp. 1955) ; ArIz. Cone ANn. $\$ \$ 62-801$ to -809 (Supp. 1952) ; Cal. Civ. Code $\S \S 3017-29$; Colo. Rev. Stat. Ann. $\S \S 11-2-1$ to -7 (Supp. 1955) ; Fla. Stat. ANN. \$§ 524.01-.06 (Sưpp. 1956) ; GA. Code ANN. \$\$ 85-1806 to -1813 (1955); IdA ho Code ANN. $\$ \S 64-901$ to -907 (Supp. 1957) ; Iowa Code ANN. $\$ \$ 539.7-.15$ (Supp. 1956) ; Kan. Gen. Stat. ANn. \$\$ 58-801 to -807 (Supp. 1955); LA. Rev. Stat. ANn. \$\$ 9:3101-:3110 (Supp. 1957); Mass. Acts 1957, c. 765, see note 32 stpra; Mo. Ann. STAt. $\$ \$ 410.010-060$ (Supp. 1957) ; Neb. Rev. Stat. $\$ \$ 69-601$ to -621 (Supp. 1955) ; N.C. Gen. Stat. \$\$ 44-77 to -85 (Supp. 1955) ; Ohro Rev. Code Ann. \$\$ 1325.01-.08 (Page Supp. 1957); Ohl.1. Stat. Anv. tit. 15, $\$ \S 631-37$ (Supp. 1957) ; PA. Star. AnN. tit. 12A, $\$ \$ 9-103$, 9-106, 9-204, 9-302, 9-401 (1) (a) (Supp. 1956) ; S.C. CoDE $\$ \$ 45-201$ to -211 (Supp. 1955) ; Tex. Rev. Civ. Stat. ANn. art. 260-1 (Supp. 1957) ; Utar Code ANn. \$\$ 9-3-1 to -6 (Supp. 1957); Vt. Acts 1953, No. 164; WAst. REv. CODE \$§ 63.16.010-.110 (Supp. 1957) ; Hawaii 
diminish one source of diversity, they combine to produce new variances among state treatment of accounts receivable financing. For example, two states permit an assignee to retain proceeds he collected without knowledge of a previous assignment. ${ }^{34}$ Under several recording acts, a subsequent assignee can,

and Puerto Rico have also enacted recording statutes. Hawaii Sess. Laws 1951, Ser. C-210: Act 45 ; P.R. LAws Ann. tit. 10, $\$ \$ 581-88$ (Supp. 1956).

The Uniforar CoMmsercial CODE $\$ 9-302$ (Mass., Pa.) does not require recording unless the assignor transfers a significant part of his outstanding accounts to one assignee. The Pennsylvania version also makes recording unnecessary when the assignment is for collection only or for reassignment by a professional assignee. The UNIFoRM ConMERCIAL CODE (1957 off. ed.) does not require filing where the assignee is a collecting bank and in reassignment cases, but only as against creditors and transferees of the original assignor.

The Michigan act, although basically a validation statute, see note 32 supra, requires filing of any assignment designed as security for an antecedent debt, except an assignment made pursuant to an agreement entered into at or before the time the indebtedness was first incurred. Mich. Stat. Ann. $\$ 19-842$ (Supp. 1955). This provision seems designed to prevent preferences obtained by back-dating yet exempts from the recording requirement regular receivables arrangements based on an underlying contract. But since governing contracts can also be back-dated, the filing requirement appears to be of little value, especially since $\$ 19.846$ of the statute abolishes the rule of Benedict $v$. Ratner. See note 45 infra.

In the first few years following the Klauder case, see note 29 supra, validation statutes were preferred by states wishing to preclude a reoccurrence of that case. Thus, while all validation statutes were enacted between 1943 and 1946, only eight states (Cal., Idaho, Mo., N.C., Ohio, S.C., Tex., Utah) had enacted filing statutes by 1946 . On the whole, finance companies favored validation statutes while banks preferred filing. Koessler, supra note 3, at 57, 87. See also recommendation of the New York Law Revision Conmission, AsSIGMarents of Accounts Recervable 6 (1946). Finance company hostility to recording seems due to fear of borrowers' unwillingness to publicize the "hocking" of their accounts, id. at 279; Phelps, Accounts Receivable Financting as a Method of Business FiNANCE 16-17, 63 (1956), and to apprehension that competitors might use recording files to steal customers. Koessler, supra note 3 , at 60,99 ; NEw YoRk LAw Revision CommissIoN, AssignMents of Accounts Recervable 279 (1946). The banks, on the other hand, felt that filing was necessary to remove the danger of double assignments. Koessler, supra note 3 , at $57-58$ n. 49 .

Most filing acts differ considerably, except for a group of five substantially identical statutes, the Idaho act having served as a model for those in Colorado, Florida, Oklahoma and Utah.

North Dakota alone has a bookmarking statute, N.D. REv. CoDE $\$ \S 9-1108,9-1109$ (Supp. 1949), which eliminates the need to notify account debtors, but requires, for perfection, that assignments be noted on the assignor's books. The statute represents an attempted compromise between advocates of recording acts-mainly banks and the bankruptcy bar-and proponents of validation statutes-the finance companies. Yet it fails to accomplish the purpose of either-an effective degree of publicity in the one case, quick and easy perfection of assignments in the other-and thus pleases neither faction. See, e.g., Koessler, supra note 3, at 95; New YoRK LAW Revision Conimissron, Assignments of Accounts Recervable 263 (1946). Pennsylvania and Georgia, formerly bookmarking states, Pa. Laws 1941, No. 255; Ga. Laws 1943, No. 178, at 263, have wisely abandoned this position by enacting filing statutes.

34. The Kansas and Vermont filing statutes allow an assignee who first recorded to recover proceeds from another assignee, except to the extent that the other assignee 
by filing, defeat only prior assignments of which he is unaware. ${ }^{35}$ Yet, other statutes favor recorded assignments despite knowledge of previous transfers. ${ }^{3 n}$ Still other recording acts indicate that filing does not protect an assignee against prior unrecorded assignments. ${ }^{37}$ Statutes also differ on: place of filing

acquired his title or interest in good faith and for value. The language, identical in both statutes, even permits interpretation favoring an attaching creditor who obtains proceeds in good faith. Moreover, in California a simple contract creditor who had extended credit before filing was allowed to recover proceeds already collected by the assignee. Menick: v. Carson, 96 F. Supp. 817 (S.D. Cal. 1951), discussed in note 39 infra. On the other hand, most statutes, both validation and recording, provide specifically or by clear implication that the assignee who first perfects his assignment may recover from any other assignee who collects the proceeds. The validation statutes of Maryland, Oregon and Rhode Island, however, are silent on this point. Restatenent, Contracts $\S 173(\mathrm{~b})$ (1932), permits a subsequent assignee to retain proceeds collected in good faith.

35. Under the statutes of Colorado, Florida, Kansas, Nebraska, Oklahoma and Vermont, the assignee who records takes subject to prior assignments of which he has written notice; in Missouri, he takes subject to such assignments if he has actual knowledge of them; and in Alabama, California, Washington, Hawaii and Puerto Rico, filing protects against subsequent assignees without notice, the statutes thus implying that a subsequent assignee with notice cannot prevail, even if he files, against a prior unrecorded assignment. The Idaho and Utah statutes define a protected assignee as the "owner of a protected assignment who took the same in good faith and for value." The Texas act contains language to the same effect. Knowledge of a prior though unrecorded assignment would clearly seem to disqualify an assignee from the protected category. Under the Nebraska statute, an attaching creditor, as opposed to a subsequent assignee, need only have actual rather than written notice of an unrecorded assignment for his interest to be subordinated to that of the assignee.

For problems occasioned by the theory that knowledge of a branch bank is imputed to the whole system, see Comment, 56 MICH. L. REv. 90 (1957).

36. The Iowa, North Carolina, Ohio and South Carolina statutes state that, as between two assignees of the same debt, the one who first files prevails. The California and Washington statutes also contain such language, but seem to prefer an assignee who first records only when he is ignorant of a prior assignment. See note 35 supra.

37. Thus, the filing statutes of Arizona, Louisiana, Hawaii and Puerto Rico, and the North Dakota bookmarking statute, hold that a perfected assignment gives the assignee superior rights to those of existing and subsequent creditors and subsequent (but not existing) assignees. The Idaho and Utah statutes favor a recording assignee against "purchasers from and creditors of his assignor whose rights in the account arose after the making of the protected assignment thereof." Both groups, particularly the first, imply that a good-faith recording assignee cannot prevail against a prior unrecorded assignment. Little commercial significance attends these differences, for double assignments are relatively rare, see note 50 infra, and the 1950 amendment to the Chandler Act eliminated the bona fide purchaser test, see note 29 supra. But the Louisiana, Washington and Hawaii statutes, in addition to containing the above provision, state that a creditor obtaining a judicial lien perfected prior to the assignment will prevail. Other statutes, e.g., Texas, imply the same rule, which might invite application of Constance v. Harvey, 215 F.2d 571 (2d Cir. 1954), reaffirmed in Conti v. Volper, 229 F.2d 317 (2d Cir. 1956), and followed in England v. Sanderson, 236 F.2d 641, 643 (9th Cir. 1956). Constance, a bankruptcy case, tested the validity of a mortgage perfected some time after execution under a New York statute which stated that simple contract creditors extending credit during the gap could defeat the mortgage, even after its perfection, by obtaining a judicial lien. While no such creditor actually existed, Bankruptcy Act $\$ 70(c), 66$ STAT. 430, 11 U.S.C. $\$ 1.10$ (c) (1952), which 
- county or state $;^{38}$ time of filing and perfection-before, simultaneously with or within a certain time after assignment; ${ }^{39}$ effective duration of filing; $;^{40}$

gives the trustee the avoiding powers of a hypothetical lien creditor under state law, was held to invalidate the mortgage. Professor Moore has interpreted Constance to empower a trustee to "set aside any transfer which any hy'pothetical judicial lien creditor could have set aside in the past." Moore, Debtors' and Creditors' Rights 656 (1955). Should this view of Constance prevail, assignments governed by the above statutes-because of the vulnerability of receivables to garnishment prior to assignment-would be endangered. However, Constance should enable reaching into the past only with respect to the extension of credit-not with respect to the acquisition of the lien. Section $70(\mathrm{c})$ vests the trustee with property upon which a hypothetical creditor could have obtained a judicial lien "at the date of bankruptcy." Thus, unless assignments remain vulnerable to judicial liens obtained at bankruptcy, Constance should be inapplicable. Other commentators endorse this interpretation. 4 ColLIER, BANKRUPTCY $\{70.51$ (Supp. 1956); Kleinberg \& Masterson, Constance v. Harvey-A Defense, 62 Conr. L.J. 124 (1957) ; Marsh, Constance v. Harvey -The 'Strong-Arm Clause' Re-Evaluated, 43 CaLIF. L. Rev. 65 (1955); Weintraub, Levin \& Beldock, The Strong-Arm Clanse Strikes the Belated Chattel Mortgage, 25 Fordenam L. REv. 261, 269 (1956).

Far from exposing the assignee to the dangers of Constance v. Harvey, some courts place a garnishing creditor in no better position than the assignor by holding that the purpose of the filing statute is to protect assignees of the same account. Oklahoma Oxygen Co. v. Citizens State Bank \& Trust Co., 274 P.2d 372 (Ol-1a. 1954) (assignments of afteracquired accounts not protected by filing statutes, yet good against attaching creditors). But see Treadwell v. A. Kristoferson, Inc., 32 Wash. 2d 145, 200 P.2d 740 (1948).

38. See text at notes 150-70 infra.

39. All filing statutes except those listed below permit filing at any time before or after an assignment and hold an assignment perfected when filed or when made, whichever is later. For example, when $A$ files before $B$ files, but $B$ obtains a prior assignment of the same account, $B$ prevails, except in so far as other provisions of these statutes, listed in notes 36,37 supra, indicate a different result. In these states, an assignee, though he knows that he filed first, must determine whether anyone filed after him before taking an assignment.

The California statute requires recording before or within five days after the assignment. As interpreted in Menick v. Carson, 96 F. Supp. 817, 819 (S.D. Ca1. 1951), a latefiled assignment is invalid as against a creditor who extended credit at any time before filing and before collection of the account; such a creditor can recover proceeds already collected by the assignee. By applying the rule of Constance v. Harvey, discussed in note 37 supra, a trustee could thus invalidate any late-filed assignment, even if no creditor had actually extended credit before filing. See Marsh, supra note 37, at 71. Provisions similar to the one in the California act are contained in the Washington and Hawaii statutes, except that time limits for filing after assignment are ten and thirty days respectively. In all three jurisdictions, the date of perfection presumably relates back to the date of assignment if notice is filed within the prescribed period. The Ohio act demands recording prior to or contemporaneously with the assignment. This statute, as well as the Washington and Hawaii statutes, can be interpreted as holding all late-filed assignments completely invalid as against third parties. The court in Menick v. Carson refused to attribute such an intent to the California legislature.

Under the North Carolina statute, an assignment, whether executed before or after filing, becomes protected as of the time of filing, provided it is made within the effective duration of the filed notice. South Carolina seems to follow the same rule.

40. In the following jurisdictions, filing is effective for one year: Ala., Ariz., Colo., Fla., Idaho, Kan., Mo., Neb., Okla., Utah, Vt., Hawaii; for two years: La.; for three years: Cal., Iowa, Mich., Ohio, S.C., Tex., Wash.; for four years: Ga.; for five years: 
types of transactions and debts to which the statute applies; ${ }^{41}$ whether notifica-

Mass., Pa., P.R. In North Carolina, filing is effective for the period stated in the filed notice. Most of the above statutes have provisions for filing of renewal statements. Only the Georgia, Iowa, Missouri and Texas acts contain no such clauses.

In Keeran v. Salley, 244 S.W.2d 663 (Tex. Civ. App. 1951), the court undermined the Texas provision making a recorded notice of assignment valid for three years. The court interpreted the statutory definition of an account receivable- "an existing or future right to the payment of money due or to become due ... under an existing contract"-as protecting only those assigned accounts which had arisen under contracts existing at the time of filing. The Texas statute was not intended to force an assignee to record each new assignment when made, as is the rule for chattel mortgage recordation. Rather, the statute was designed to permit general notice filing at relatively long intervals in the manner of the UNIFORM TRUST RECETPTS ACT $\$ 13(4)$. The real purpose of the definition upon which the court based its decision was to require separate assignments of accounts as they arise instead of separate recordings, and thus prevent the assignment of accounts to arise in the future. See note 44 infra. See also Republic Nat'l Bank v. Vial, 232 F.2d 785 (5th Cir. 1956). Texas changed its statute to foreclose reoccurrence of the Keeran result. But the Colorado, Florida, Idaho, Nebraska, North Carolina, Oklahoma, Utah and Vermont statutes all contain language similar to the former Texas definition, and general notice filing in these states may therefore be impaired. While the Ohio statute also has such language, other provisions are sufficiently clear to make a Keeran result unlikely.

41. The definitions of an assignment and of an account receivable vary considerably among statutes. Typically, an assignment includes any transfer, sale, pledge or mortgage of an account receivable, or of a part thereof. Transfers by operation of law are not included in the Kansas, Texas and Hawaii definitions. Other statutes require the assignor to be in a business or profession (Ala.), or to be either a wholesaler or one who renders services for hire under a contract (Kan.). The California statute applies only to assignments made in the regular course of business.

Accounts receivable are sometimes defined as rights to payment for goods sold, leased or transferred, or for services rendered (Ohio, UnIForm CoMmmerCIAL Code \$ 9-106; Iowa requires these transactions to have taken place in the regular course of business). Most statutory definitions embrace only amounts due or to become due on open accounts or contracts. As to whether a contract must exist at the time of assignment, see note 44 infra. Filing and validation acts generally exclude one or more of the following categories from the definition of accounts receivable and thus from the scope of the statute: (1) rights represented by judgments, negotiable instruments, chattel mortgages, conditional sale contracts or other instruments required to be recorded (e.g., Cal., see In re Richards, $108 \mathrm{~F}$. Supp. 259 (S.D. Cal. 1952) (bank's purchase of conditional sales contract with reservation of a percentage of price as protection against default not within statute), Ohio, Conn., Minn., Uniforar CoMrmercial CoDE \$§ 9-104(f), 9-106) ; (2) a nonnegotiable instrument which so represents the obligation that an assignee in possession of the document has rights superior to other claimants (Fla., see M. M. Landy, Inc. v. Nicholas, 221 F.2d 923 (5th Cir. 1955) (government warrant held capable of being pledged and therefore excluded from the Florida recording requirement) ; Colo., Neb., Tex., Vt. and others have similar requirements); (3) wages (Ala., Ark., Conn., Iowa, Minn., Neb., N.H., UniforM CoMmercial CODE $\$ 9-104$ (d); Iowa excludes wages by statutory implication and decision, Peterson v. Ball, 121 Iowa 544, 97 N.W. 79 (1903) (construing an almost identical earlier section); while Maryland and North Dakota include wages by statute, and Colorado, whose statute is silent on the point, includes them by decision, Ware v. Barr, 126 Colo. 311, 248 P.2d 1073 (1.952)); (4) sums due under construction contracts (Ala., Cal., Ga., Iowa, Neb., N.C.; Texas allows such assignments if the land is described in the notice which must be filed in the county where the land is located) ; (5) amounts due from preharvest sale, by 
tion arrangements need be filed $;^{42}$ and whether an assignment must be for value. ${ }^{43}$ Several validation and filing statutes change the common-law rules on

grower, of farm crops (Neb.) ; (6) obligations evidenced by life insurance policies (Minn., N.H.) or any insurance policy (UNIFORM COMIMERCIAL CODE $\$ 9-104(\mathrm{~g})$ ) ; (7) tort claims and bank or savings deposits (UnIForMr CoMmirerctal CODE $\S 9-104(\mathrm{k})$ ); (8) sums due from the United States (Ala., Ga.).

Assignments of federal debts, of course, come under the Assignment of Claims Act of 1940, 54 StAT. 1029, as amended, 31 U.S.C. \$ 203 (1952), which provides that an assignment within its terms shall constitute a "valid assignment for all purposes." Whether this phrase enables an assignment perfected under the act to prevail as against another assignment favored by state statute is unclear. Cases supporting both views exist. For exclusiveness of the federal statute, see General Cas. Co. v. Second Nat'l Bank, 178 F.2d 679 (5th Cir. 1949) ; Coconut Grove Exchange Bank v. New Amsterdam Cas. Co., 149 F.2d 73 (5th Cir. 1945). Contra, Royal Indemnity Co. v. United States, 117 Ct. Cl. 736, 93 F. Supp. 391 (1950); Hardin County Sav. Bank v. United States, 106 Ct. Cl. 577, 65 F. Supp. 1017 (1946). Yet these cases involve competing claims of sureties on government contractors' performance bonds and financing banks. And the exclusiveness issue is probably obscured by policy considerations transcending the Assignment of Claims Act. See 41 VA. L. Rev. 984 (1955).

That the present Claims Act affects only rights against the government, not between third parties, is suggested by interpretations of the pre-1940 act. Act of Feb. 26, 1853, c. $\$ 1, \S 1,10$ Stat. 170. Although this statute declared assignments of government claims "absolutely null and void," cases held that such assignments could be valid as between assignor, assignee and everyone else except the government; questions of validity and priority among assignees were then governed by state law. Martin v. National Surety Co., 300 U.S. 588 (1937) ; California Bank v. United States Fidelity and Guaranty Co., 129 F.2d 751 (9th Cir. 1942). And, in a case decided after the 1940 amendment, the Third Circuit ruled that state law determined priority as between a trustee in bankruptcy and an assignee of moneys to become due under a government contract. In re Italian Cook Oil Corp., 190 F.2d 994, 997 (3d Cir. 1951). See also Note, 101 U. PA. L. REv. 106, 121-22 (1952) (state law governs if the assignment does not comply with the act). Six state accounts receivable statutes (Kan., N.C., Ohio, S.C., Tex., Vt.) exclude assignments which are subject to special provisions of other state or federal acts. These exclusion provisions might be read as encompassing the Claims Act as well as acts such as those governing assignments of wages and assignments for the benefit of creditors.

42. The Missouri and North Carolina statutes recognize notification of the account debtor as an alternative to filing. The Georgia statute states that filing is merely an additional method of giving notice and does not abolish other methods. Although Georgia courts have never decided that the English rule obtains in the state, see note 26 supra, the provision implies that notice to account debtors would constitute an effective substitute for recordation.

43. Several statutes do not mention the need for giving of value. E.g., Me., Md., Mich., Va., S.C., S.D. Among the statutes requiring consideration, the majority makes transfers for an antecedent obligation perfectible. Ala., Ariz., Colo., Conn., Fla., Idaho, Kan., Minn., Neb., N.H., N.C., Ohio, Utah, Vt., Hawaii, P.R., Uniform Commerctal Code § 1-201 (44) (1957 off. ed.), $\$ 9-108$ (1) (1952 ed.). Others simply require a valuable consideration, leaving unanswered the question whether an antecedent debt will qualify. Ill., Ind., La., Okla., Ore., Wash., Wis. Under common law, an assignment made to secure an antecedent debt is generally held to have been made for value. 2 Wirliston, Contracts \& 438A (rev. ed. 1936).

States also differ on the manner of executing assignments: many statutes, e.g., Mich., Minn., Okla., Tex., Utah, require a written assignment to be "delivered" before it can 
after-acquired accounts. ${ }^{44}$ Moreover, most either abolish the rule of Benedict

become perfected. This rule contrasts with the provision of some statutes, e.g., La., permitting an assignment to be completed by notation on the assignor's books. Under the UNIFORM COMMERCIAL CODE $\$ 9-203$ (1) (b), the assignor must sign a security agreement.

44. The Uniforar Commercial Code $\$ 9-204$ (3) and the Iowa, Michigan and Texas statutes give effect to assignments of accounts to arise in the future, even though "the particular account is not contemplated" (Iowa), or the contract under which it is to arise is "not then in existence" (Mich., Tex.). The Texas statute requires assignments to describe present and future accounts with sufficient particularity to identify them; the UNIFORM COMMERCIAL CODE $\$ 9-110$ requires reasonable identification. These statutes changed the common law on this point in Iowa, Massachusetts and Texas. In re Estate of Nelson, 211 Iowa 168, 233 N.W. 115 (1930); Taylor v. Barton Child Co., 228 Mass. 126, 117 N.E. 43 (1917) ; First Nat'l Bank v. Campbell, 193 S.W. 197 (Tex. Civ. App. 1917). Prior to statutory enactment, Michigan common law already recognized the validity of assignments of future book accounts. Union Trust Co. v. Bulkeley, 150 Fed. 510 (6th Cir. 1907). The Kansas statute may approve assignments of after-acquired accounts. It defines an account as "an existing or future right to the payment of money." The "future right" may be interpreted to refer to money not yet due but to become due under an existing contract or obligation. Had this been the draftsman's intent, however, such traditional language as "an existing right to future payment" would probably have been used. Whether Kansas common law allowed assignments of accounts to arise in the future is uncertain. See Chatterton v. Clayton, 150 Kan. 525, 95 P.2d 340 (1939) (assignment of heir's expectancy good against garnishor) ; Schmidt v. Plummer, 140 Kan. 436, 37 P.2d 1 (1934) (denying, as against creditors, effectiveness of an after-acquired property clause in a chattel mortgage) ; Morris v. Nelson, $124 \mathrm{Kan}$. 127, 257 Pac. 729 (1927) (seeming to require a further act to insure assignment). In any event, the implied statutory acceptance of Benedict $v$. Ratner, see note 45 infra, weakens the interpretation that assignments of after-acquired accounts are protected, since the two doctrines are, in policy, incompatible. Cf. NEw YoRK LAw Revision CoMmission, Studx of Unifora Commerctal Code, Article Nine 154 (1955).

Eleven statutes limit protection to assignments of existing or future rights to payment under an existing contract. Colo., Fla., Idaho, Ill., N.C., Ohio, Okla., Utah, Vt., Wis., Hawaii. Four states achieve the same result by referring to rights under an unperformed contract; the implication being that contracts must at least exist. Ariz., Cal., Ind., Wash. In H. S. Mann Corp. v. Moody, 144 Cal. App. 2d 310, 301 P.2d 28 (1956), the court recognized this implication but viewed another reference in the California statut: to "accounts to arise in the future" as indicating legislative intent to continue common-law protection of assignments of after-acquired accounts. The Connecticut and New Hampshire statutes further restrict protection to assignments of sums to become due for goods completed or services rendered under an existing contract. But see the New Hampshire Factors' Lien Act, N.H. REv. STAT. ANN. \$§ 446:1-:10 (Supp. 1957), which has been interpreted to authorize assignments of accounts to arise in the future, even though the accounts did not arise from liened inventory, provided notice was filed under the act. Perkins v. Lakeport Nat'l Bank, 139 F. Supp. 898 (D.N.H. 1955). Eleven statutes define accounts as sums due or to become due on open accounts or contracts. Ala., Arli., Ga., Me., Md., Minn., R.I., S.C., S.D., Va., P.R. Whether this type of statute refers to both existing and future contracts is unclear. As in the California case cited above, a court will undoubtedly be influenced by the common law in effect before enactment of the statute. See Clanton Bank v. Robinson, 195 Ala. 194, 70 So. 270 (1915) (futurt accounts not assignable); Baskin v. Aetna Life Ins. Co., 190 Ark. 448, 79 S.W.2d 724 (1935) (assignable) ; Ainsworth v. Mobile Fruit \& Trading Co., 102 Ga. 123, 29 S.E. 142 (1897) (not assignable). In Northwestern Nat'l Bank v. A. M. Cameron Co., 210 F.2d 398 (8th Cir. 1954) (applying Minnesota law), such accounts were held nonassignable, 
v. Ratner or modify its extreme applications to returned goods and price adjustments. ${ }^{45}$

Choice of law is thus likely to determine most cases testing multistate accounts receivable financing transactions. Admittedly, conflicts problems are

but, in denying a rehearing, 212 F.2d 484 (8th Cir. 1954), the court implied that future accounts might be assignable if the assignment properly identified accounts arising under future sales.

The Nebraska statute, while defining an account as a right to payment under an existing contract, provides elsewhere that all items in an open or running account, even though added subsequent to the assignment, shall be deemed included in the assignment. Thus, future accounts with existing customers are assignable. Louisiana's statute, which also refers to an open, running or book account, possibly permits the same interpretation. No implication can be read into the Missouri or Oregon statutes; the common law will thus stand. See Bissell v. Hill, 10 Mo. App. 593 (1880) (future debts assignable; semble). The North Dakota bookmarking requirement makes assignments of after-acquired accounts impossible. See also the New York and New Jersey factors' lien acts permitting assignments of future accounts in notification arrangements. Note 30 supra.

Assignments of accounts to arise in the future, even when allowed by state law, may well be voidable in bankruptcy to the extent that the accounts arose within four months of bankruptcy. Trustees can claim that under Bankruptcy Act $\S 60,64$ STAт. 24 (1950), 11 U.S.C. $\& 96$ (1952), assignments of future accounts were made for antecedent debts and are therefore invalid (if the other requirements of $\$ 60$ are met). The Uniform COMMrerctal CODE $\$ 9-108$ anticipates the argument by providing that the secured party's interest in after-acquired collateral "shall be deemed taken for new value and not as security for an antecedent debt." The effectiveness of this section is doubtful. New York Law Revision Comarisston, Study of Uniform Comamercial Code, Articte NINE 136-39, 172-73 (1955). Perhaps a successful means of avoiding $\$ 60$ invalidation would be to assign existing accounts up to a certain total amount, and provide that as new accounts arise they shall automatically be substituted for the oldest outstanding accounts so that the assignee's lien will cover a constant total amount of receivables. The release of liens on old accounts would thus serve as present consideration for the automatic acrrual of liens on new accounts.

45. See text at notes 17-22 supra. Statutes in the following jurisdictions repudiate Bencdict v. Ratner by stating in effect that the assignee's lien shall not be affected because of permission given to the assignor freely to use proceeds as they are collected without accounting for them: Ga., Mich., N.C., Ohio, S.C., Wash., UNIForM Commerctal Cone $\$ 9-205$ ( $\mathrm{Pa}$., Mass.), Hawaii. A majority of statutes, however, provide only that assignments shall be unaffected by the assignor's dealing with returned goods as his own property or by his granting credits, allowances or adjustments to the account debtor. Ala., Ariz., Cal., Colo., Conn., Fla., Idaho, Kan., Me., Minn., Mo., Neb., N.H. (but see discussion of factors' lien acts infra), Tex., Utah, Vt., P.R. Accordingly, only the extreme application of Benedict, see note 19 supra and accompanying text, is abolished in these states, and, by implication, the remainder of the rule is legislatively sanctioned. See Malcolm, supra note 17, pp. 36-37. The Arkansas statute makes an assignor trustee for the benefit of the assignee "of all sums paid by the account debtor in good faith." By thus labeling the rights and obligations of the parties, the statute may be construed as protecting their relationship against Benedict's fraud-in-law doctrine. When not mentioned in statutes, Bcncdict will probably persist where formerly applied. Mount v. Norfolk Sav. \& Loan Co., 192 F.2d 286 (4th Cir. 1951) (applying Virginia law). But the exclusiveness of statutory precepts has been urged as grounds for departing from Benedict precedent. $C f$. Colbath v. Mechanicks Nat'1 Bank, 96 N.H. 110, 70 A.2d 608 (1950) (Benedict, although common law, held abolished as to inventory since Factors' Lien Act contains no express 
usually of minor significance when presented in suits brought by an assignee against account debtors who have paid either the assignor or a subsequent assignee, or who claim setoffs. For the near uniformity of state statutes and decisions gearing account debtors' liability to actual notice of the plaintiff's assignment and preserving to them all defenses available against their assignors at the time of notification relegates choice of law to the background of such litigation. ${ }^{46}$ Similarly, disputes between assignor and assignee rarely

provision with regard to the rule); Second Nat'l Bank v. Phillips, 189 F.2d 115, 118 (5th Cir. 1951) (suggesting that the Texas filing statute, by removing the vice of secrecy, makes full adherence to Benedict less important).

Several statutes give the assignee a lien on returned goods; all of these except the Illinois act attach qualifications. For example, in Minnesota the lien is given against all but a bona fide purchaser of the goods, or, in North Carolina, a bona fide purchaser or a "lienee" (sic). The Washington statute provides a lien if the goods are segregated, and the South Carolina act affords a lien against general and judgment creditors of the assignor. In the 1956 Recommendation of the Editorial Board, the Uniform Commercial Code for the first time deals with the returned goods problem in receivables financing. Subsections 9-306(5) (c), (d), give the assignee a security interest in the goods against the assignor, but subordinate it to a security interest existing in the goods before sale. To be good against creditors of the assignor, the assignee's lien must be perfected, i.e., filed.

Only the North Carolina statute deals with accounts arising from resale of returned goods; it gives the assignee an automatic lien on such receivables.

Several factors' lien acts affect Benedict's application to accounts receivable whenever the filing requirement of that act is fulfilled. Thus the New Hampshire act, N.H. REv. Stat. Ann. \$ 446:7 (Supp. 1957), abolishes the rule entirely, even with respect to accounts which arose from goods not subject to a factors' lien, while the Minnesota and Wisconsin acts repudiate Benedict only with respect to accounts arising from liened merchandise, Minn. Stat. Ann. § 514.89 (Supp. 1957); Wis. Stat. \$241.145(10) (1955). Nine acts permit the assignor to exercise dominion over returned inventory and to make price adjustments, irrespective of whether the goods from which the accounts arose were subject to a lien. Ala. Code tit. 47, $\$ 132(6)$ (Supp. 1955) ; Ill. Ann. Stat. c. $82, \$ 10 \$$ (Smith-Hurd Supp. 1957) ; Ind. Ann. Stat. \$ 43-1205 (Supp. 1955); ME. Rev. Stat. Ann. c. 181, \$ 8 (Supp. 1957) ; Miss. Code Ann. $\$ 382-16$ (1956) ; N.J. Stat. ANn. \$ 2A:44-183 (Supp. 1957) ; N.Y. Pers. Prop. Law \$ 45; Tex. Rev. Crv. Stat. Ann. art. 5506 (c), \$6 (1956) (adjustment only) ; W.VA. Code ANn. \$3946(22) (Supp. 1957). Finally, the Vermont act renounces the adjustments and returned goods rule for accounts which arose from liened goods only. VT. STAT. \$ 2748 (1947).

46. Nearly all assignment of accounts receivable statutes provide that an account debtor is discharged pro tanto when he deals in good faith with the assignor, creditors of the assignor, a subsequent assignee or other successors in interest. Yet variations exist. Some statutes mention only payment by the account debtor to the assignor (Ariz., Iowa, Utah, UNIForM COMrMERCTaL CODE \$ 9-318(3)) or to the assignor or a subsequent assignee (Md., Minn., Ore., R.I.). Others hold an account debtor liable only if he makes such payment after receiving a notice in writing (Fla., Kan., La., Neb., Tex., Vt.) or after receiving a copy of the notice actually filed with the secretary of state (Colo.). Many statutes discharge an account debtor not only if he has made money payment in good faith, but also if he has given a negotiable instrument, entered into a novation or is subject to a final judgment on the debt (e.g., Ala., Conn., Ind., N.H.). Other statutes which speak in terms of satisfying (e.g., Me.), discharging (e.g., Md.), or simply paying (e.g., Mo.) the debt probably achieve the same result. But the Idaho and Utah statutes 
feature conflicts issues concerning the validity of assignments. ${ }^{47}$ Applicable

mention only "money payment," apparently excluding the other means of satisfaction, $c . g$., novation, as a defense by the account debtor against the assignee. Only four statutes do not deal directly with payment made by the account debtor to someone other than the assignee, but three of these (Ga., N.D., Okla.) provide that filing, or bookmarking as the case may be, shall not constitute notice to the account debtor, thus implying the same rule as the other statutes. The Michigan statute perhaps arrives at the same result by making any recipient of proceeds accountable to the protected assignee.

Statutory protection of good-faith account debtors who have paid once is consistent with the generally accepted common-law rule. See Wolters Village Management Co. v. Merchants and Planters Nat'l Bank, 223 F.2d 793 (5th Cir. 1955) ; First State Bank v. Pure Van Pipe Line Co., 77 F.2d 820 (5th Cir. 1935) ; Patten v. Mutual Benefit Life Ins. Co., 192 S.C. 189, 6 S.E.2d 26 (1939). See also Koessler, supra note 3, at 63; Kupfer, Accounts Recoizable Financing: A Legal and Practical Look-See (Part 1), The Practical Lawyer, Nov. 1956, pp. 50, 57, 59; New York Law Revision Commission, Assignments of Accounts Receivable 23 (1946).

The majority of statutes make an assignee's claims against an account debtor subject to any defenses, setoffs or counterclaims which the account debtor had against the assignor at the time of receiving notice of the assignment (e.g., Cal., Conn., Minn.). Other states have enacted the same rule in statutes permitting assignees to sue in their own name. See, e.g., Iowa Code Ann. \$\$ 539.1-.3 (Supp. 1957) ; Mp. ANN. Code art. 8, $\$ \$ 1,4$ (Supp. 1956); VA. Cone ANN. \$ 8-94 (1957). And the common law accords with this rule. Continental Purchasing Co. v. Van Raalte Co., 251 App. Div. 151, 295 N.Y. Supp. $\$ 67$ (4th Dep't 1937) ; Ertel v. McCloskey, 167 Pa. Super. 120, 74 A.2d 652 (1950). A few aberrational accounts receivable statutes exist. For example, the Colorado statute allows the account debtor all defenses, counterclaims and setoffs arising before or after notice of the assignment; the Utah statute permits no setoffs, etc., based on any claim which the debtor acquired after the assignment (not notice of the assignment as in the other statutes) ; Idaho has the same rule except that claims of breach of express or implied warranty arising after the assignment are allowed; in Ohio, breach of warranty claims discovered after notice to the account debtor may also be maintained; the Arkansas statute preserves to the account debtor defenses against the assigned account, rather than defenses against the assignor. Finally, the Michigan and New Hampshire statutes and the Uniform Conarercial Cone $\$ 9-318$ (1) (a) afford the account debtor any rights or defenses given by the contract from which the account arose.

State laws also differ on an account debtor's right to restrict assignability. In Allhusen v. Caristo Constr. Corp., 303 N.Y. 446, 103 N.E.2d 891 (1952), the New York court held that an account debtor may effectively forbid an assignment of his obligation by inserting a clause in the contract or purchase order to that effect. The Caristo dactrine is followed in a large majority of jurisdictions. See, e.g., Parkinson v. Caldwell, 126. Cal. App. 2d 548, 272 P.2d 934 (1954); Lewin and Sons, Inc. v. Herman, 143 Conn. 146, 120 A.2d 423 (1956); Annot., 37 A.L.R.2d 1251 (1954). Contra, Uniform ComMERCLA $C_{1}$ UL $\$ 9-31 S(4)$. An assignment, however, will always be good as between assignor and assignee. Freitag v. The Strand, Inc., 205 F.2d 778 \& n.4 (3d Cir. 1953). And it has been held that the Caristo doctrine cannot be invoked by third parties. Tezel \& Cotter v. Roark, 301 S.W.2d 179 (Tex. Civ. App. 1957).

47. Moreover, notification of account debtors has always been held irrelevant to the validity of assignments as between the immediate parties. Koessler, supra note 3 , at 63 . See R. F. Ball Constr. Co. v. Jacobs, 140 F. Supp. 60 (W.D. Tex. 1956), upholding an unrecorded assignment against a tax lien on the ground that recording of an assignment under the Texas statute would not affect validity between original parties, and that 56 STAT. 957 (1942), 26 U.S.C. $\$ 3672$ a (1952), protects mortgagees, including assignees, from a tax lien subsequently filed. Nevertheless, courts go both ways on whether $\$ 3672 a$, 
state law is ordinarily stipulated by the parties. ${ }^{48}$ Irrespective of stipulation, solvent assignors normally contest debts rather than assignments. ${ }^{40}$ Claims against insolvent assignors, on the other hand, generally involve bankruptcy litigation where validity of assignments is most frequently challenged by an assignor's trustee in bankruptcy. In these cases, as well as in nonbankruptcy suits occasioned by attachment of assigned accounts or double assignments, conflicts questions are commonly raised. ${ }^{50}$ Typically, an assignor's place of business is situated in one state, the assignee's in another, and account debtors are in several additional localities. ${ }^{51}$ Further complications may arise when the assignor resides in still another jurisdiction or has widespread branch offices, or when the assignment is executed in a state having no other contact with the transaction. The reference to many jurisdictions thus made possible combines with the marked contrariety of their laws to make choice of law an often dispositive issue.

Despite the prominence of conflicts issues in accounts receivable transactions, courts have failed to develop workable precepts to guide the business community. In choosing laws to govern multistate arrangements, they have utilized conflicts doctrines developed in contract or chattel security decisions. ${ }^{62}$ Although

which subordinates tax liens to any prior "mortgagee, pledgee, purchaser, or judgment creditor," applies to assignments of accounts. Kupfer, Accounts Receivable Financing: A Legal and Practical Look-See (Part 2), The Practical Lawyer, Dec. 1956, pp. 55, 59-60.

48. But stipulation of law is ineffective as against third parties. See, e.g., Maguire v. Gorbaty Bros., 133 F.2d 675 (2d Cir. 1943) ; In re Vardaman Shoe Co., 52 F. Supp. 562, 565 (E.D. Mo. 1943) ; Smith v. Harris, 127 Cal. App. 2d 311, 314, 273 P.2d 835, 836 (1954), discussed in note 163 infra.

49. If the solvent assignor is in fact indebted to the assignee, the validity of the assignment is for most purposes irrelevant as between these parties. The assignee is primarily interested in recovering his money. See Weiss v. Balaban, 315 Mass. 390, 53 N.E.2d 83 (1944) (absent specific agreement, assignee need not look only to assigned accounts for satisfaction of assignor's debt but may sue assignor directly on debt before collection of accounts; fact that assignments were partial and therefore not enforceable at law immaterial since assignee sued on debt).

50. Double assignments, however, are relatively rare. Kupfer, Accounts Reccivable Financing: A Legal and Practical Look-See (Part 1), The Practical Lawyer, Nov. 1956, pp. 50, 57; see New York Law Revision Coarmission, Assignments of Accounts Receivable 268 (1946). That the problem can nevertheless arise in commercial accounts receivable lending is indicated by the case of State Factors Corp. v. Sales Factors Corp., 257 App. Div. 101, 12 N.Y.S.2d 12 (1st Dep't 1939). See also note 108 infra.

51. " $[I] t$ is far more frequent to find the account debtor, the assignor, and the assignee to be domiciled in two or three separate states than to find all of them domiciled in one." Kupfer \& Livingston, Corn Exchange National Bank \& Trust Company v. Klandor Revisited: The Aftermath of Its Implications, 32 VA. L. Rev. 910, 915 (1946). See also Uniforar Conmarcial Code $\$ 9-103$, comment 2 (1952 ed.); Coblens, Assignments of Accounts Receivable as Security-The Situation in Oregon, 29 ORE. L. REv. 214, 216 (1950).

52. See text at notes 58-97 infra. The absence of a uniformly accepted conflicts rule in this area is underscored by numerous commentators. E.g., Koessler, supra note 3, at 47; New York Law Revision Comarssion, Assignarents of Accounts Receivadle 261, 291 (1946). Illustrating the confusion in the English case of Republica de Guatemala 
such rules may adequately serve their own fields, they have limited value in the accounts receivable area. Most traditional doctrines allow courts to select relevant state law from among many contact jurisdictions. ${ }^{53}$ Furthermore, different rules are often applied to different aspects of a single receivables arrangement. ${ }^{54}$ The availability of several established conflicts rules, and the wide choice of reference offered by most, precludes sound prediction of the state whose law will ultimately govern a multistate transaction. Financers and borrowers must therefore conform assignments to varying substantive laws and comply with the filing requirements of many jurisdictions. The increased expenditure and risk attending such difficulties most likely enhances interest rates and impairs the free extension of business credit.

Erratic choice of law also frustrates conflicts principles. The primary objective of conflicts doctrine is uniformity of result-choice of law should not vary with fortuitous choice of forum. ${ }^{55}$ Uniformity could, of course, be accomplished in the receivables area by universal application of any traditional doctrine. But a conflicts rule is unlikely to gain universal acceptance unless it complements the policy considerations of the substantive legal context in which it operates. ${ }^{56}$ So viewed, ad hoc selection of law in accounts receivable financing may be explained by the inadequacy of established doctrines to fulfill commercial needs. ${ }^{57}$ Because of the significance imported to conflicts issues by

v. Nuñez, [1927] 1 K.B. 669 (C.A.), in which four judges proposed five different conflicts rules for the assignment of a debt.

53. See text at notes 58-97 infra, pointing out that under the lex situs rule five differunt jurisdictions may be chosen; that the place of performance may not be clearly located in one jurisdiction; that the center of gravity doctrine involves value judgments on the importance of different contact points and thus outcome will vary among courts; and, finally, that even the place of assignment can not always be located with certainty.

54. According to the Restatearent of CoNFutcts (1934), for example, the assignability of an account is governed by the law of the place in which that obligation was contracted $(\$ 348)$. The law of the place of assignment tests the effect of an assignment as between assignor and assignee, as well as the legal capacity of the assignor and the formalities required to effectuate an assignment ( $\$ \S 350-52$ ). The rights of an assignee against an account debtor who has paid the assignor or a second assignee are determined by the law of the place of performance of the assigned contract ( $\$ \$ 353-54$ ). See also Smith v. Harris, 127 Cal. App. 2d 311, 273 P.2d 835 (1954) (formal validity of assignment Foverned by law of place of assignment; necessity of notice, recording or possession determined by law of situs) ; 3 Rabel, CoNFLict of Laws 401-16 (1950).

55. "It is frequently asserted, or assumed, that the dominant objective, indeed the very raison d'être, of Conflict of Laws is uniformity." Freund, Chief Iustice Stone and the Conflict of Laws, 59 Harv. L. Rev. 1210, 1211 (1946). See also Nussbaum, Private INTERNATIONAl, LAW 21 (1943) (tracing uniformity concepts back to Savigny).

56. "[Uniformity] will be attained according to the measure of universality with which conflicts rules commend themselves by their good sense to the judgment of courts and legisiators." Freund, supra note 55, at 1212. Cf. Mishkin, The Variousness of "Federal Laze"; Conpetence and Discretion in the Choice of National and State Rules for Decision, 105 U. PA. L. REv. 797, S08 (1957), urging the same idea in advocating a federal conflicts rule. See also text at notes 174-81 infra.

57. An additional explanation is judicial predilection for the laws of the forum whenever plausible support is available. See note 70 infra. The existence of a multiplicity 
divergent state laws and the disruptive effect of unpredictable choice of law, a rule should be sought which can subserve business requirements as well as effectuate the objectives of conflicts doctrine.

\section{Lex Situs}

\section{Traditional Doctrines}

Finding precedent in chattel transfer cases ${ }^{58}$ and a tenuous analogy between chattels and receivables, some courts apply lex situs to multistate assignments. 0 Due to their intangible nature, accounts receivable are variously situated at five localities : ${ }^{60}$ the assignor's domicile or place of business, ${ }^{61}$ the locus of

of conflicts doctrines facilitates the exercise of this "homeward trend." Nussbaum, Private Internationad Law 37 (1943).

58. See Lattve, The Transfer of Chattels in the Conflict of Laws 44-102 (1955) ; Zaphiriov, Transfer of Chattels in Private International Law $39-49$ (1956). The UnIFora COMMerctaI CODE $\$ 9-102$ adopts the situs rule. While lex situs has even been given a constitutional setting in chattel transfer cases, Warner v. Jaffray, 96 N.Y. $* 248,257$ (1884), this notion is generally rejected.

59. For an example of this line of thought see Smith v. Harris, 127 Cal. App. 2d 311, 314-15, 273 P.2d 835, 836-37 (1954). Whether a debt can have situs has been questioned. Proponents of rules other than lex situs base arguments against its applicability on a seeming contradiction in terms in the expression "situs of an intangible." See, e.g., 39 HARv. L. REv. 485 (1926). They maintain that situs is where a state has in rem jurisdiction and, since there can only be in personam jurisdiction over an intangible, debts are incapable of having a situs. But the dispute is sterile. Debts undoubtedly do have situs for certain purposes, e.g., for taxation (domicile of creditor), for the administration of estates (domicile of debtor or debtor's person), for insurance (same). Andrews, Situs of Intangibles in Suits Against Nonresident Clainants, 49 YALE L.J. 241, 255 (1939) ; Baker, Administration of Intangibles, 19 Mo. L. REv. 1, 9 (1954); 30 Sr. JoHN's L. Rev. 224, 225 (1956). Whether a debt should be considered as having situs for assignment purposes is, therefore, the only meaningful inquiry.

60. In the case of an assignment of a tort debt, a sixth locality has been used-the place where the tort suit was brought. Williams v. Ingersoll, 89 N.Y. 508,523 (18S2).

61. In re Dalpay, 41 Minn. 532, 43 N.W. 564 (1889) (situs at assignor's domicile, in forum state, though assignor's place of business elsewhere); In $r c$ Vardaman Shoe Co., 52 F. Supp. 562, 565 (E.D. Mo. 1943) (dictum; assignor's place of business) ; Hanna v. Lichtenhein, 182 App. Div. 94,169 N.Y. Supp. 589 (1st Dep't 1918), rev'd on other groutds, 225 N.Y. 579, 122 N.E. 625 (1919) (dictum; court mentions both place of assignment and lex situs, both at assignor's place of business); Flanagan, Assignnents of Accounts Receivable and the Conflict of Law's Under the Bankruptcy Act, 2 VAND L. REv. 409, 422 (1949) (using the maxim mobilia sequmitur personam-see note 173 infra-situs is considered to be at the assignor's place of business) ; STORY, CoNflict of LAws $\$ 362$ (8th ed. 1883) ; cf. Dix v. Bank of Cal. Nat'1 Ass'n, 113 F. Supp. 823 (N.D. Cal. 1952) (assignor's domicile; rule used as alternative to place of assignment rule which leads to same jurisdiction). For a listing of other advocates of this version of $l c x$ situs, see 3 Rabel, Conflict of Laws 391-92 (1950). In Fenton v. Edwards \& Johnson, 126 Cal. 43, 58 Pac. 320 (1899), the court, employing the maxim mobilia sequntur personam, found that situs was not in California (where the account debtor was garnisheed) but then used the place of assignment rule to determine which foreign law applied. 
book accounts or bills receivable, ${ }^{62}$ the account debtor's domicile or place of business, ${ }^{63}$ the place where the debt is garnisheed, ${ }^{64}$ or the jurisdiction whose law governs the assigned debt. ${ }^{65}$ Most often, situs has been established at the place of garnishment or the account debtor's domicile. And few practical considerations militated against use of the rule, for the cases generally concerned assignments of personal debts or individual business accounts.

But associating account debtors with situs would be impracticable in largescale financing. Borrowers frequently assign debts of customers who are located in several jurisdictions. ${ }^{66}$ Determining the validity of such arrangements by referring to contrary state laws would obviously be an unfeasible task for a bankruptcy tribunal. In nonbankruptcy litigation, ordinarily initiated by garnishment, such administrative difficulties could be avoided by choosing the law of the forum. Besides disrupting conflicts policy-results would vary with the "accident" of jurisdiction-this version of lex situs would force lenders to satisfy filing and other requirements in any state in which account debtors were likely to be found. ${ }^{67}$ Indeed, to safeguard the security of all assigned accounts, compliance with forty-eight state laws would be necessary. Only then could assignments be protected against the contingency of account debtors

62. Union Trust Co. v. Bulkeley, 150 Fed. 510, 517 (6th Cir. 1907) (one of three alternative rules, the others being the place where the assignment is to be performed and the assignor's place of business; all three led to the same result).

63. Lewis v. Bush, 30 Minn. 244, 15 N.W. 113 (1883) (also stands for the proposition that situs is where the debt is payable) ; Republica de Guatemala v. Nuñez, [1927] 1 K.B. 669, 697-98 (C.A.) (concurring opinion by Lawrence, L.J.; "quasi-situs" of debt in England, though place of assignment, assignor and assignee located in Guatemala); In $r e$ Maudslay, Sons \& Field, [1900] 1 Ch. 602, 610; Jabbour v. Custodian of Absentee's Property of State of Israel, [1954] 1 All E.R. 145 (Q.B. 1953); FalConbRidge, Conflict of Laws 418 (1947). This is also the modern French doctrine. 3 Rabel, Conflict of Laws 392 (1950). Dicey once advocated the rule, Dicer, Conflict of Laws 566 (3d ed. 1922), but later abandoned it in favor of the proper law of the debt, DicEy, Conflict of Laws 573 (6th ed. 1949).

64. Smead v. Chandler, 71 Ark. 505, 76 S.W. 1066 (1903); Westlake, Private INTERNATIONAL LAw $\$ \$ 150-52$ (7th ed. 1925) (the law of the forum for the recovery of a debt; in case of an account debtor with branch offices, e.g., a bank, only at the branch where the account payable is kept); cf. In re Queensland Mercantile \& Agency Co., [1891] 1 Ch. 536, aff'd, [1892] 1 Ch. 219.

65. This version, usually labeled "proper law of the debt" rather than lex situs, is advocated by many English and continental writers. Batiffol, Assignments, Micr. Sumaier Inst. 48, 50 (1951); Cheshire, Private International Law 450 (4th ed. 1952); Foote, Private International Law 296 (5th ed. 1925); Schnitzer, Fandbuch des Internazionalen Handels-, Wechsel- und Checkrechts 218 (1938); WolfF, Private INTERNATIONAL LAW 548 (1945) (pointing out that German, Swiss and Scandinavian laws follow this rule); cf. Monarch Discount Co. v. Chesapeake \& O. Ry., 285 Ill. 233, 120 N.E. 743 (1918) ; Lewis v. Bush, 30 Minn. 244, 15 N.W. 113 (1883); Runkle v. Smith, 89 N.J. Eq. 103, 103 Atl. 382 (Ch. 1918).

66. See Malcolm, Conflicts of Laws, Accounts Receivable, Mass. L.Q. Oct. 1945, pp. $38,39,41$.

67. When account debtors are corporations operating several branches at which they can be garnisheed, the unreasonableness of the burden becomes even more apparent. 
moving to uncovered jurisdictions. Locating situs at the jurisdiction whose law governs the assigned debt would be equally undesirable for commercial arrangements. A multiplicity of relevant jurisdictions would again make the rule unworkable in bankruptcy and generally disruptive of business needs. ${ }^{68}$

Equating situs with the assignor's home office would afford a practicalile solution. ${ }^{60}$ General application of the law of the state in which the assignor centers his business would produce uniformity of result irrespective of forum. Predictability thus afforded, borrowers and lenders could safely conform assignments to one set of filing and substantive laws. The interests of challenging parties would also be served in that the existence and validity of these security arrangements would be more readily ascertainable.

Nevertheless, the lex situs doctrine should be abandoned in the receivables field. Adherence to the label might induce some courts to depart from a home office solution in favor of the rule's unserviceable alternatives-reassociation of situs with account debtors. Commentators have often observed courts' predilections for the laws of their own jurisdiction. ${ }^{70}$ Since nonbankruptcy suits involving assignments are usually initiated by garnishment of accounts, courts could find justification for applying their own forum's laws in the plasticity of the lex situs doctrine. ${ }^{71}$ Moreover, the usual reason advanced for accepting lex situs is irrelevant to the context of accounts receivable financing. As applied to chattel transfers, lex situs is justified as protecting unsecured creditors who may have known of the chattels and looked to them for possible satisfaction in the event of default. ${ }^{72}$ When an assignor conducts business in several states, unsecured creditors might similarly rely on inventory located in a branch office. But since every state fully protects buyers in the ordinary course of trade, ${ }^{73}$

68. Moreover, application of this rule would necessitate recourse to an additional conflicts doctrine and thus further obstruct needed predictability. Deciding that a debt's situs is located in the jurisdiction whose law governs the assigned debt, the court must then apply the conflicts rule of contracts to the original transaction between the assignor and the account debtor. Another element of uncertainty is thus introduced by the availability of several divergent conflicts doctrines in the contracts field. See discussion of these doctrines as applied to assignments in text at notes 74-97 infra.

69. See text beginning at note 98 infra, advocating a lex loci commerciendi rule.

70. "[T] he natural predilection of the judge for the lex fori ... is, in all countries, the most important single factor in the shaping of conflicts rules in practice." Kahn-Freund, The Proper Law of a Contract and Affreightment, 17 Modern L. Rev. 255 (1954). See also Nussbaum, Private International Law 37 (1943); Goodrich, Two States and Real Estate, 89 U. PA. L. Rev. 417 (1941); cf. also HARPER \& TAIntor, Conflict of LAws 175 (1937).

71. "'Situs' seems to be one of those words by which nothing can be really explained, but everything justified." Koessler, New Legislation Affecting Non-Notification Finaning of Accounts Receivable, 44 MicH. L. Rev. 563, 610 n.199 (1946).

72. LALIVE, op. cit. supra note 58 , at 51 . Story supported the rule with principles of territoriality: "[T] he laws of every state affect and bind directly all property, whether real or personal, within its territory ...." STORY, Conflict of LAws $\$ 18$ (Sth ed. 1883).

73. Cf. Gilmore, The Commercial Doctrine of Good Faith Purchase, 63 Yale L.J. 1057 (1954). 
such reliance must cease, as a practical matter, when the inventory is sold. More significantly, proceeds of particular sales-cash and accounts receivable -are easily dissipated and thus are not realistically subject to the expectations of unsecured creditors. Rather, once inventory leaves the debtor's premises, general creditors can only rely on honesty and the continued solvency of the going business.

\section{Place of Assignment}

The place of assignment, most frequently consulted for applicable law in accounts receivable financing, ${ }^{74}$ is also an unsuitable conflicts reference. Choosing the law of the place where an assignment is executed is an extension of the lex loci contractus rule used in ordinary contract situations. ${ }^{75} \mathrm{As}$ applied to multistate accounts receivable arrangements, the rule affords some predictability and uniformity of result. ${ }^{76}$ Yet, while a place of assignment doctrine disarms

74. See, e.g., In re Rosen, 157 F.2d 997, 999 (3d Cir. 1946) (although the court mentions other contact points, it clearly indicates that the place of assignment is the determinative rule). The place of assignment rule is thought by many to be the generally accepted conflicts rule in the field. See, e.g., L. Hand, J., in New England Mut. Life Ins. Co. v. Spence, 104 F.2d 665, 666-67 (2d Cir. 1939) ; NEw York LAw Revision Consisssion, Assignurents of Accounts Receivable 283 (1946). Many commentators support the rule. 2 BeALE, Conflict of LAWS $\$ 348-54$ (1935); Goodrich, Conflict of LAws $\$ 110$, at 321-23 (3d ed. 1949); Minor, ConfLict of Laws $\$ 122$ (1901) ; REstatement, Conflicts $\$ \S 350,352$ (1934). The Restatement's influence can be seen in the fact that courts sometimes cite it without any other authority. See, e.g., Barbin v. Moore, 159 Atl. 409 (N.H. 1932). But see notes 52 supra, 173 infra. Yet the rule is criticized as referring to the least important of all points of contact and as substituting fortuity for reason. WolfF, Private International LaW 552 (1945).

75. Restatement, Conflicts $\$ 332$ (1934).

76. While the place of assignment rule gives the greatest predictability among the traditional doctrines, uncertainty is not eliminated. For example, the borrower may execute an underlying agreement in Michigan, assigning all his accounts, present and future, to the lender. Returning to his home state, the assignor would send weekly schedules of new accounts to the assignee. A court may reason either (1) that Michigan law governs because it holds assignments of future accounts valid, and all accounts to arise in the future were assigned there; or (2) that the law of the assignor's home state is applicable since each account could be assigned only as it came into existence in that state-that law not recognizing assignments of after-acquired accounts. In sum, a problem of "characterization" (or "qualification") is presented: definition of the "making of an assignment." Some courts will look to the substantive law of one of the assignment states in order to resolve this problem as a "preliminary question," while others may obviate characterization by restating the conflicts rule in a way that clearly identifies the place where the assignment was made. For discussions of varying approaches to the problem of characterization, see, e.g., Nussbaun, PrIvate International Law 79-90 (1943); RoBertson, Characterization in the Conflict of Laws (1940).

Another area of possible uncertainty may be illustrated by In re Eby, 39 F.2d 76 (E.D. N.C. 1929). The assignor signed the contract of assignment in North Carolina and sent it, along with the schedules of assigned accounts, to the assignee in Maryland. The court held that since the contract was not effective until accepted by the assignee in Maryland, the place of assignment was in Maryland. See also McKibbin v. Ellingson, 58 Minn. 205, 59 N.W. 1003 (1894), where an assignment was made in Minnesota to a Minnesota assignee 
forum shopping at the litigation stage, it may encourage parties to seek lenient jurisdictions upon transacting assignments. Choice of law depends on an event - signing a paper, mailing a schedule of accounts-which may be effected in a state having no other contact with the transaction. Accordingly, the recording statutes and substantive restrictions of contact states can be avoided at the option of the parties. ${ }^{77}$

Moreover, a "mailbox" determination of applicable law cannot be cognizant of successive assignments executed in different jurisdictions following different laws. For example, a borrower might assign the same set of receivables in two different states, first to $A$, then to $B$ who notifies account debtors. $A$ 's state may protect his claim against $B$, while under the law of $B$ 's state, $B$ would prevail by virtue of prior notification. Conflicting standards of priority thus make the place of assignment an unfeasible rule for litigation precipitated by double assignments. ${ }^{78}$ More important, the rule is equally ill-adapted to contests between creditors of the assignor and a single financer. Initial assignments

by an assignor who did business in North Dakota. That the assignment was filed in North Dakota (under an assignment for benefit of creditors statute) induced the court to consider recordation as the final act of assignment and thus hold North Dakota law controlling.

For the difficulties which may arise in connection with ascertaining the lex loci contractus, see CooK, Logical and Legal Bases of the Conflict of Laws c. 14 (1942); 2 RABEL, Conflict of LAws 452-62 (1947).

77. See New York Law Revision Commission, Assignaients of Accounts ReCEIVABLE 283 (1946), testimony of Milton Kupfer, pointing out the possibility of evading New York law, if found burdensome, by establishing Connecticut branches for clearing assignments. Accord, id. at 259. See also Flanagan, supra note 61, at 421 . While Mr. Kupfer's testimony was given in opposition to a proposal to enact a filing statute in New York, it well illustrates the unsatisfactory nature of a place of assignment rule. Indeed, a court in a jurisdiction which disallows assignments of after-acquired accounts, note 23 supra, and which follows the rule of Benedict $v$. Ratner, note 17 supra, is not likely to validate assignments made in a state which has neither restriction, particularly when the assignor transacted all his business in the forum state.

78. The Restatement recognizes this problem and therefore provides a different rule for double assignments-the law of the place of performance of an assigned contract. Restatenient, Conflicts $\S 354$ (1934). Accord, Stumberg, Conflict of Laws 262 (1951). The Restatement section in fact refers to suits by an assignee against an account debtor who has paid a second assignee. Yet it has been generally interijeted to refer to suits between competing assignees as well. See, e.g., referee's opinion cited in $I n r c$ Rosen, 157 F.2d 997, 999 n.7 (3d Cir. 1946) ; two unreported cases, the Hebeler and Nizolek cases, cited by Koessler, New Legislation Affecting Non-Notification Financing of Accounts Receivable, 44 Micr. L. REv. 563, 608-09 (1946). According to his treatise, however, Professor Beale (author of the Restatement) would have the law of the place of assignment govern whenever both assignments are made in the same jurisdiction or in different jurisdictions having the same law. When assignments are made in jurisdictions with different laws, the assignee who first protected himself against subsequent assignees under the laws of the state where his assignment was made, prevails. 2 BEALE, CONFLICT of LAws $\$ 354.1$ (1935). Accordingly, $A$ would have the superior claim in the text example above. For criticism of the cases used by Professor Beale to support his view, see Flanagan, supra note 61 , at 417 . Professor Beale's rule has the disadvantage of requiring reference to separate state laws, including, presumably, laws concerning after-acquired accounts and retained dominion-Benedict v. Ratner. See notes 17-24 supra. Moreover, under this rule, 
in accounts receivable arrangements are typically executed in conjunction with the basic continuing credit contracts at the financer's place of business. All subsequent assignments of accounts are ustrally effected at the home office or various branch offices of the assignor. Piecemeal testing of the arrangement by two or several divergent state laws would be a cumbersome and irrational method to resolve conflicting rights in what is functionally a single course of dealing. ${ }^{79}$

\section{Place of Performance}

Another traditional contracts rule-place of performance-has been suggested by courts for determination of accounts receivable conflicts issues. ${ }^{80}$ Place of performance is variously used in contract cases. ${ }^{81}$ Under one variation, usually employed in connection with lex loci contractus, each aspect of performance is governed by the law of the place in which it occurred. Another method of applying the rule with lex loci contractus results in testing all aspects of performance by the laws of the place in which contractual obligations were principally fulfilled. Occasionally, the principal place of performance is consulted for all issues-execution as well as performance-arising out of the transaction. An aspect approach may prove serviceable in ordinary contract suits where parties dispute isolated parts of each other's performance. But since the major litigation engendered by accounts receivable financing concerns the validity of entire assignments, ${ }^{82}$ the rule, if extended to the receivables field, need be used as a principal place of performance doctrine. Extension of credit and assignment of accounts constitute the essential performances in an accounts receivable transaction. If judicial inquiry were thus limited, the assign-

neither assignee would have any practical way of investigating the possibility of another assignment.

The Restatcment provision, as interpreted by the cases cited above, at least makes such prediction possible. For the place of performance of the assigned debt may be more readily cognizable under one of the standard contract rules of conflicts. Should applicable law then demand filing or notification of account debtors, an assignee might ascertain prior assignments. If neither filing nor notification is required, the assignee knows that he cannot rely on the absence of superior claims. Yet the Restatement rule which is similar to the "proper law of the debt" doctrine, see notes 65,68 supra, contains the same disabilities. And adherence to a uniform conflicts rule applicable to all possible cases in addition to double assignments is preferable. See text beginning at note 98 infra.

79. For a discussion of the branch office problem, see text at notes 108-11 infra.

80. Courts refer either to the place of performance of the assigned contract, see note 84 infra, or the place of performance of the assignment arrangements, see, e.g., Union Trust Co. v. Bulkeley, 150 Fed. 510 (6th Cir. 1907).

81. For discussions of place of performance doctrine in contracts, see, e.g., Nussbauns, Private International Law 172-75 (1943); 2 Rabed, Conflict of Laws 463-69 (1948).

82. This is the case in bankruptcy litigation. See, e.g., Lee v. State Bank \& Trust Co., 38 F.2d 45 (2d Cir. 1930), decree modified, 54 F.2d 518 (2d Cir. 1931) ; Mount v. Norfolk Sav. \& Loan Corp., 192 F.2d 286 (4th Cir. 1951). The validity of assignments of individual accounts is ustally challenged by unsecured creditors in garnishment cases. See, e.g., Smith v. Harris, 127 Cal. App. 2d 311, 273 P.2d 835 (1954). 
ment would probably be considered a more significant feature than the loan, and the rule would consequently resolve into the unworkable place of assignment doctrine. ${ }^{83}$ However, courts suggesting the relevancy of the performance location seem to situate it at the place where proceeds of assigned accounts are collected. ${ }^{84}$

Gearing the performance rule to the place of collection might furnish some predictability in the nonnotification field. Nonnotification agreements require the assignor to collect accounts and remit proceeds to the assignee. ${ }^{85}$ Should performance be associated with collection, the principal place of performance would probably be considered the assignor's home office. Remission, however, could easily be construed as a more important component of the collection process. And if the assignee's bank-the place of remittance-is not located in the assignor's state, the law of another jurisdiction would be introduced. Such precedent, once settled, could be harmful when nonnotification agreements permit an assignor to place collected proceeds in different banks located near multistate branch offices.

Even if an actual collection-performance equation were established in nonnotification cases, its application to notification transactions would remain problematical. In notification arrangements, assignees receive payment from account debtors. ${ }^{86}$ Courts wishing to follow the rule in such cases would have to decide whether an assignee's collection is performance under the terms of the governing contract. Assumption of this burdensome and sometimes expensive process may be considered by the assignor as bargained-for consideration reflected in the purchase price of accounts. But since the assignee in nonrecourse notification assignments bears all risks of noncollection, ${ }^{87}$ failure of collection entails no loss to the assignor. So viewed, an assignee's collection would not constitute contractual performance; and a collection version of the performance doctrine would be inapplicable to notification financing. Consequently, even limiting performance to the mechanics of collection does not avoid unwanted speculation.

Broadening the scope of the rule to embrace all phases of performance could only be justified on flexibility grounds. Mechanical conflicts doctrines are often criticized as preventing adaptation of relevant law to heterogeneous transactions. However, if flexibility is desired, judicial inquiry need not be confined

83. See notes 74-79 supra and accompanying text. If the loan were considered more significant, the rule would resolve into the assignee's place of business, which has never been suggested as a governing doctrine, see text following note 183 infra, the assignor's place of business, discussed infra in text beginning at note 97 , or, again, into the place of assignment.

84. Actually, place of collection is often synonymous with the place of performance of the assigned debt, used by the Restatenient, Conflicts $\$ \S 353,354$ (1934), in suits between assignees and account debtors. See note 78 supra. It also comes very close to the "proper law of the debt" rule. See note 65 supra.

85. See notes 5-12 supra and accompanying text.

86. See note 3 supra and accompanying text.

87. See note 4 supra and accompanying text. 
to the contractual performance. Rather, applicable law can best be geared to specific arrangements by examining all transactional events under a center of gravity approach.

\section{Center of Gravity}

The center of gravity rule ${ }^{88}$ selects the law of the state with which the transaction had most substantial connections. ${ }^{89}$ During the past twenty years, center of gravity has received growing judicial recognition in contract cases. ${ }^{90}$ Similarly, severil decisions in the receivables field, though not explicitly referring to the rule, have employed its principles. ${ }^{91}$ Center of gravity is a theory of conflicts based on notions of territoriality and appropriateness, which excludes a rigid choice of law dependent on some arbitrarily selected feature of the contract. ${ }^{92}$ Implementation of the rule accordingly entails evaluating the relative significance of all events or "contacts" generated by a given transaction and permitting the greatest accumulation of important connections to determine applicable law..$^{93}$ Certainty is, of course, foregone when contact points seem evenly distributed between two or more jurisdictions. And abuse of the rule's flexibility may be induced by customary judicial predilections for the laws of the local forum. ${ }^{94}$ Thus, center of gravity reflects a balancing process between diminished predictability and the risk of jurisdictional accidents on the one hand, and recognition that diverse situations require flexible standards on the other.

But balancing these interests in the context of accounts receivable financing demonstrates, instead, the need for a mechanical doctrine. Divergent state laws and pronounced requirements for the free extension of business credit make

8S. Center of gravity has also been termed "accumulation of contact points," HARPER \& Taintor, Conflict of Laws 173 (1937), "proper law," Ehrenzweig, Interstate and International Conflicts Law: A Plea for Segregation, 41 MinN. L. Rev. 717, 722 (1957), and "grouping of contacts," Auten v. Auten, 308 N.Y. 155, 161, 124 N.E.2d 99, 102 (1954).

89. See, e.g., Harper \& TaINTOR, CoNflict of LAws 173-75 (1937).

90. See, e.g., Barber Co. v. Hughes, 223 Ind. 570, 63 N.E.2d 417 (1945); Auten v. Auten, 308 N.Y. 155, 124 N.E.2d 99 (1954); Ehrenzweig, supra note 88, at 722.

91. See, e.g., Union Trust Co. v. Bulkeley, 150 Fed. 510 (6th Cir. 1907) (discussing intention of parties, place of performance, assignor's place of business, etc.) ; In re Rosen, 157 F.2d 997 (3d Cir. 1946).

92. Territoriality embraces the notion that the laws of a state have an interest, so to speak, in a transaction when an event connected therewith occurred or is to occur in that state, or when a person or thing involved in the transaction is located in that state. HARPER \& TAINTOR, CONFLICT OF LAwS 173-75 (1937). "[T] his grouping of contacts theory may, perhaps afford less certainty and predictability than the rigid general rules ..." Fuld, J., in Auten v. Auten, 308 N.Y. 155, 161, 124 N.E.2d 99, 102 (1954).

93. 'The 'contacts' that are weighed and counted are not chosen from a particular list, nor do they represent actual contacts between the parties, but they are simply all the major and minor points picked, arranged and evaluated by the court as relevant to a decision of the conflicts question." Note, 40 CoRNELL L.Q. 772, 777-78 (1955).

94. See note 70 supra. 
predictability a more critical consideration in the receivables area. ${ }^{95}$ Possibilities of multijurisdictional litigation also portend a greater risk of results varying with fortuitous choice of forum than in ordinary contract cases. Moreover, while contract cases feature diverse situations, ${ }^{96}$ receivables transactions follow relatively stable factual patterns. If then, one contact in the arrangement significantly and generally outweighs other transactional events, it could form the basis of a rule which would not only complement center of gravity principles but also obviate the attendant disabilities. The assignor's place of business, which emerges as a predominant contact in virtually all assignment transactions, suggests such a rule—lex loci commerciendi. ${ }^{97}$

\section{Lex Loci Commerciendi}

The conflicting interests which give rise to most accounts receivable litigation should measure the significance of contact points and thus indicate proper choice of law. Assignees' security interests in accounts receivable are most often contested by assignors' general creditors, either individually or represented collectively by a trustee in bankruptcy. Underlying each suit are the discordant class interests of both parties. Unsecured creditors demand strict safeguards against secret liens and preferential or fraudulent transfers..$^{98}$ Assignees, on the other hand, to promote safe financing, require security which is easily obtainable and obviously valid. ${ }^{99}$ Disparities in state treatment of assignment transactions primarily derive from differing attitudes on the proper balancing of these conflicting interests. The contact point at which both generic interests are most likely to be personified by the particular litigants should be considered predominant and therefore determine the state whose law should resolve the conflict.

95. See text at notes $30-45$ supra; note 15 supra.

96. "The transactions of the business world are so numerous and of such a variety that it is difficult, if not impossible, to formulate a general rule that should control in all cases ..." Wilson v. Lewiston Mill Co., 150 N.Y. 314, 322, 44 N.E. 959, 961 (1S96).

97. The term, only recently coined, see Note, 66 YALE L.J. 567, 577 (1957), is not used without hestitation. But impalatable as a new Latin phrase may be, it seems justified as a shorthand expression for "the law of the assignor's principal place of business." Moreover, the universal acceptance of the traditional term lex loci contractus facilitates understanding of lex loci commerciendi. Admittedly, the expression is not entirely accurate in that it refers only to the place of doing business, not the principal place of doing business. But insertion of an adjective or adverb would make the term unwieldly and frustrate the purpose of its use.

98. See Koessler, Assignments of Acconnts Receivable, 33 CaLIf. L. Rev. 40, 60 n.59 (1945). In Corn Exchange Nat'l Bank \& Trust Co. v. Klauder, 318 U.S. 434, 441 (1943), the Court implied that nonnotification financing, permitting secret liens, prejudices unsecured creditors.

99. Businessmen wish to avoid not only losing law suits but litigation itself, for the costs of a suit, though won, can easily wipe out the profit margin of a given transaction. "Imprecise standards encourage litigation and may lead commercial lending institutions to take unnecessary precautions; each of these consequences will increase the cost of loans." Note, 66 Y ALE L.J. 257, 265 (1956). 
Accordingly, the law of the state in which the assignor conducts his business should govern accounts receivable financing. While the assignee may not operate his business in this state, his interest-facilitation of credit-is synonymous with that of his borrower in the context of bankruptcy or garnishment litigation. The assignor's desire to obtain credit must, of necessity, coincide with the assignee's need to acquire security interests upon which credit can be safely extended. Thus, the assignee's interest is represented by the assignor in the latter's jurisdiction. Concurrently, unsecured creditors tend to be clustered near the assignor's place of business, ${ }^{100}$ and this state, more than any other, is likely to have a direct concern in their protection. ${ }^{101}$ Admittedly, a balancing of interests rationale does not invariably lead to the assignor's place of business in such rare actions as those between two assignees of the same accounts or the immediate contracting parties. ${ }^{102}$ Nevertheless, the assignor's place of business not only represents an essential contact point in most of these contests, ${ }^{103}$ it constitutes the only rule which can practicably solve the conflicts problems they occasion. ${ }^{104}$ Furthermore, application of other rules in minor actions would frustrate uniformity and predictability objectives. While assignees could insure validity against garnishing creditors by satisfying the laws of the assignor's jurisdiction, effectiveness against assignors and second assignees could only be attained by conforming assignments to multiple state laws. More important, a more perfect representation of interests in some infrequent actions should not justify departure from a general rule which embodies the fairest

100. Flanagan, suipra note 61 , at 424 ; see Note, 66 Y ALE L.J. 567, 579 (1957).

101. See Flanagan, sipra note 61 , at 422 , arguing that the assignor's state of business is the jurisdiction most interested in enforcing its public policy on recording (prevention of fraudulent transfers) and assignments of future accounts (protection of the assignor's solvency).

102. See notes 47,50 supra.

103. "The only suitable contact of accounts receivable is with the business place where the books are conducted." 3 RabeL, Conflict of LAws 432 (1950). On the importance of the place where the books are kept in contrast to the principal place of business, see notes 127-33 infra and accompanying text.

104. In opposing the rule of the assignor's residence or place of business, Cheshire argues that it may lead to absurd results. He posits the hypothetical of an English resident assigning a debt governed by French law and owed by a German, to an Italian resident in Italy, and then again to a Swiss resident in Switzerland. The assignee, claims Cheshire, cannot reasonably expect to be subjected to English law. Cheshire, Prrvate INTERNATIONAL LAW 448 (4th ed. 1952). The point may be admitted, but, given the confusion in this field, an assignee cannot afford to rely on any one law. Legally advised, he will comply with the laws of all jurisdictions made relevant by existing doctrines -including the law of the assignor's residence. Hence, the real problem is to simplify compliance by achieving uniformity of conflicts rules. See note 56 supra. While the reasoning in favor of lex loci commerciendi applies to commercial as well as noncommercial situations (in which case it becomes the lex domicilii), the arguments are, of course, stronger in the interstate receivables financing context. For any rule requiring application of many separate laws places unjustifiable burdens on financers. See text at notes 58-97 supra. Perhaps a separation of interstate and international conflicts rules is indicated. See Ehrenzweig, supra note 88. In practice, such a separation seems to exist. Mueller, Book Review, 45 CALIF. L. REv. 394, 396 (1957) (critical). 
balance in the bulk of cases and provides the only workable solution in all classes of litigation.

Lex loci commerciendi, moreover, is not inconsistent with recordation objectives. ${ }^{105}$ Trade creditors seldom examine public records; larger unsecured creditors and second assignees probably rely on their own evaluation of the assignor's honesty and prospective sales volume. ${ }^{100}$ To the extent recordation is necessary to give general creditors and other assignees an opportunity to check, filing need be required only where interested parties can be expected to look-at the assignor's place of business. ${ }^{107}$ Selecting, under lex loci commerciendi, the law of a state with no recording requirements would not prejudice creditors who have no way of knowing, or are uninterested in ascertaining. whether the records of limitless other contact jurisdictions contain notice of an assignment. Indeed, requiring assignees to comply with recordation statutes outside of an assignor's state would obstruct liquid accommodation without affording correlative protection.

105. Opinions differ as to the real purpose of filing. It is argued that its chief utility, with the possible exception of real estate, is not to prevent deception of creditors at the time they extend credit but to prevent the assertion of fraudulent and preferential security interests after the debtor is insolvent. Koessler, Assignnents of Accounts Receivablc, 33 CAlIF. L. REv. 40, 41 (1945) (foreword by Professor Hanna); cf. New YoRk LAw Revision Commission, Assignments of Accounts Receivable 300 (1946). But sec testimony of representative of unsecured creditors arguing that filing of assignments, like recordation of chattel mortgages, is desirable to prevent extension of unsecured credit upon the strength of the apparent ownership of receivables, id. at 258-59. Accord, Menick v. Carson, 96 F. Supp. 817 (S.D. Cal. 1951) (purpose of statute is to prevent secret liens and transfers which deceive a creditor who extends or continues credit on the basis of the debtor's financial position); UNIFORM CONIMERCIAL CODE $\S 9-103$, comment 2 (1952 ed.) (purpose of filing is to allow subsequent creditors of the assignor to determine the true status of his affairs). Prevention of preferences by general notice filing is limited to cases where no filing existed before the preferential transfer was attempted. Where a notice is filed by the assignee before the four-month period, any chose in action not included in the financing arrangement may nevertheless be assigned and back-dated. unless, perhaps, the filing statute requires a description of assigned accounts. E.g., MinN. Stat. Ann. \$ 521.02 (Supp. 1956).

106. Recordation, in practice, is of little help to potential creditors dealing with the assignor. See New York Law Revision Conmission, Assignirents of Accounts ReCEIVABLE 6 (1946). At the hearing of the Commission, witnesses differed on this question, one asserting that the only way for a potential creditor to find out the assignor's real situation is to ask for a balance sheet, $i d$. at 265 , while another believed recording would lower interest rates by making lending less hazardous, $i d$. at 270 . See also Hanna, The Extension of Public Recordation, 31 CoLuM. L. REv. 617, 634 (1931).

107. In Smith v. Harris, 127 Cal. App. 2d 311, 316, 273 P.2d 835, 837 (1954), the court stated that not requiring the assignee to record in the account debtor's state "is not unreasonably inconsiderate of prospective creditors, for in the normal course of commercial transactions, the logical place in which to ascertain credit responsibility is at the place of business or residence of the assignor. The credit potential of a Texan will be reflected more accurately and expeditiously by examining the records of his business or home county in Texas than by laboriously looking to the residences of various and scattered account debtors, one of whom is in California." 


\section{Multistate Branch Office Problem}

No deviation from lex loci commerciendi is indicated when the assignor operates branch offices in several states-the law of his principal place of business should apply. Admittedly, a representation of interests approach might only sporadically select the law of the home office state, since unsecured creditors of multistate businesses are likely to be grouped near branch offices. A branch operation, however, is precisely the situation in which impracticality outweighs the fairness to parties derived from choosing the state with an integral concern-through representation-in the interests litigated. Each creditor's claim against an assignment would have to be tested by the laws of the state containing the branch office with which he dealt. When, for example, branch $A$ creditors garnishee accounts which arose in that state, application of state A's law might seem a fair selection. But a more difficult case is posed when a branch $B$ creditor garnishees branch $A$ accounts in state $A$. Holding either that this creditor deserves state $A$ law protection or carries state $B$ law into the litigation would fail to subserve the purpose of dividing applicable law according to branch office states. Nevertheless, while neither result is rational, one is necessary. And such a rule would be as likely to occasion uncertainty as the traditional doctrines.

A branch office division of applicable law would be particularly undesirable in bankruptcy litigation. ${ }^{108}$ Since bankruptcy courts must determine the validity of assignments as against all general creditors, interpretation of the laws of every state containing a branch would be required. Even if such extensive adjudication were feasible, no logical method appears of apportioning accounts or their proceeds to the claims of prevailing creditors. One procedure implied by several state statutes would be to test the assignmen't of each account by the laws of the branch state in which it arose. ${ }^{109}$ Yet the policy underscoring application of separate laws presupposes a balance between the conflicting interests of general creditors and assignees in the state in which such creditors traded with the assignor. If no unsecured credit were extended to the assignor at a branch, the law of its state would be properly inapplicable even though accounts there came into existence. The greater the divergency in each state between the proportion of unsecured credit and the percentage of arising accounts, the less purposeful such a branch state division of applicable law becomes. And since the largest share of unsecured credit is likely to be advanced at manufacturing branches where fewest accounts arise, parcelling the validity of accounts according to the state of their inception is an undesirable approach. ${ }^{110}$

108. Conflicts problems in this field most frequently arise in bankruptcy litigation. Malcolm, Conflicts of Lazes, Accounts Receivable, Mass. L.Q., Oct. 1945, pp. 38, 41.

109. See discussion of the Uniform Commercial Code and the Ohio statute, notes 154-60 infra and accompanying text. Of course, ledgers may be kept at the head office or at regional branch offices rather than the local outlet. Several other statutes seem to require recording whenever a branch office is located in the state. See notes 165, 168-70 infra and accompanying text.

110. For example, assume assignor has manufacturing branches in states $A, B$ and $C$, and sales branches at $X, Y$ and $Z$. Accounts receivable arise, of course, mainly in these 
Alternatively, assigned accounts might be prorated in proportion to unsecured credit extended at each branch. Apart from the difficult task of determining the size of an operation requisite to branch status, courts employing this procedure would confront the problem of ascertaining the branch with which each creditor traded directly. More generally, any division of applicable law would place considerable burdens on secured parties. Financing arrangements, initially safe, would be jeopardized by the establishment of new state outlets. Absent immediate filing and conformation to substantive requirements, assignments could be avoided in bankruptcy by all creditors dealing with the new branch. ${ }^{111}$

In addition to providing the only serviceable rule, lex loci commercicndi complements state substantive law designed to protect general creditors. The deficiencies inherent in other doctrines principally derive from their reference to a multiplicity of jurisdictions. ${ }^{112}$ Free from the multiplicity defect, lex loci commerciendi denotes the state best suited to the protection of unsecured creditors. Restrictions placed on security transfers are typically aimed at safeguarding creditors against Benedict $v$. Ratner violations and inducements to rely on ostensible business health. Even were branch office records fully accessible, creditors could not safely rely on the accounts or apparent prosperity of a branch operation. Any justifiable reliance on a company's ability to meet obligations must be induced, if at all, at the home office. ${ }^{113}$

Similarly, Benedict precepts contemplate the principal place of business. Three interpretations of Benedict's equivocal rationale prevail. Some courts explain the decision as founded on the conceptual incompatibility of an absoltte transfer with unfettered dominion by the transferor. ${ }^{114}$ If, in fact, Benedict rests on mere conceptualism, it has no design to protect any party. ${ }^{115}$ Conmentators, on the other hand, suggest that Benedict prevents fraudulent back-

latter states, $50 \%$ at $X, 30 \%$ at $Y$ and $10 \%$ at $Z$, with the remaining $10 \%$ distributed among $A, B$ and $C$. Unsecured creditors (suppliers, repairmen, employees), on the other hand, extend credit principally at the manufacturing branches, $40 \%$ at $A, 30 \%$ at $B$, $20 \%$ at $C$, with $10 \%$ at $X, Y$ and $Z$ together. Ninety per cent of the accounts would thus be tested by the laws of states where only $10 \%$ of the credit was extended. Yet the only valid justification for using a law other than that of the chief place of doing business is that the state where a creditor may have been induced to extend credit should govern the validity of a lien. If this policy is to be effectuated, the total amount of accounts would have to be apportioned in relation to the percentage of credit extended at each branch and tested accordingly. See text following.

111. And conceivably the whole assignment would be void in bankruptcy under the "part bad, all bad" doctrine of Browen v. Leo. See note 186 infra.

112. See note 53 supra.

113. See note 107 supra; cf. Koessler, Assignments of Accounts Receivable, 33 CALIF. L. Rev. 40, 41 (1945) (foreword by Professor Hanna): "Original extension of credit is not based upon ostensible ownership but upon financial statements, business recommendations and personal inquiry."

114. See L. Hand, J., in Brown v. Leo, 12 F.2d 350, 351 (2d Cir. 1926) : "[T]he doctrine [of Bcnedict $v$. Ratner] has nothing to do with ostensible ownership. Therefore it can rest only upon some supposed conceptual repugnancy between the mortgage and the reserved power, quite regardless of any evils which may result from their coupling."

115. Ibid. 
dating of accounts to escape preferential transfer treatment under section sixty of the Bankruptcy Act.116 The argument runs that proof of an assignee's policing, and hence of the assignor's prompt delivery of proceeds, entails records of remitted checks. Absent presentation of such evidence, a Benedict violation is presumed; with such evidence, back-dating is impossible. But since states adhering to the Benedict rule permit the assignor to substitute new accounts in lieu of remitting proceeds, ${ }^{117}$ back-dating safeguards are effectively eliminated. ${ }^{118}$ Finally, Benedict may be viewed as embracing a policy against "too easy" security transfers. 119 Implementation of this policy requires more than individual branch compliance. Over-all company observance of Benedict strictures, dictated by the home office, would be necessary. In sum, since reliance can only be induced and Benedict observed at an assignor's principal place of business, the viability of both protective measures should be determined by the law of that state. ${ }^{120}$

A principal place of business approach should also govern perfection requirements. ${ }^{121}$ Notice afforded by recordation of accounts receivable assignments

116. See Note, 101 U. PA. L. REv. 392, 395-96 (1952).

117. See note 22 supra.

118. Thus, the assignor and assignee could back-date a financing agreement to some time prior to the four-month limit and then back-date schedules which were supposedly shipped periodically and which appear to substitute new accounts arising during the selected period for accounts whose proceeds were then collected and retained. The assignment of new accounts would be viewed as made in consideration for the simultaneous release of old collateral. They would therefore have been made for present consideration, and be valid even though executed within four months of bankruptcy.

119. This policy underlies the requirement that a clear intention to preserve the property as security must be shown. See National City Bank v. Hotchkiss, 231. U.S. 50 (1913); Chapman v. Emerson, 8 F.2d 353 (4th Cir. 1925).

120. Similar arguments may be made with respect to the rule governing assignments of future accounts. Short of a conceptualistic justification, NEw YORK LAW REvisroN Commission, Assignarents of AcCounts Receivabie 65 (1946); see note 23 supra, the rule must be premised on either protection of unsecured creditors or protection of assignors against lenders who would force encumbrancing of all present and future property, see note 101 stipra. Certainly, the state of the assignor's principal place of business should determine what safeguards are needed by assignors. As to protection of unsecured creditors, the same law is most relevant, unless a multiplicity of jurisdictions is to be invoked. Multiplicity disadvantages are discussed in the earlier paragraphs of this section.

121. Some features of assignment transactions may require rules other than $l_{e . x}$ loci connmerciendi. In this connection, it is said that the contract, i.e., promise of assignment, is quite different from the assignment proper which is a transfer of property. Judge Goodrich, in In rc Rosen, 157 F.2d 997 (3d Cir. 1946) ; 3 RabeL, Conflict of Laws 389, 412 (1950) ; Flanagan, supra note 61, at 422-23; WolfF, Private Internationar. Law 538 (2d ed. 1950). True, the underlying financing agreement in a receivables assignment is different from the actual assignment of accounts effectuated periodically by the sending in of new schedules. But this does not mean that different conflicts rules need be applied. The reasons advanced for lex loci comnnerciendi with respect to assignments are applicable to the contract: the assignor's place of business is the most important single contact point, and the assignor's jurisdiction is the one most affected by the financing arrangement which, though susceptible of division into individual parts for the purpose of analysis, remains an 
is intended to benefit second assignees or an assignor's general creditors. ${ }^{122}$ Despite the existence of a multistate branch system, assignees probably transact business directly at the assignor's head office. To the extent subse-

organic whole, a single commercial relationship. But, even if contracts were to be judged by separate conflicts rules, the assignor's jurisdiction should still be chosen. Both the center of gravity rule and the doctrine of party autonomy permit this result. And it will coincide with the jurisdiction of performance of the arrangement in most cases. See notes 80-87 supra and accompanying text. Only lex loci contractus would be obstructive, but this rule has limited vitality. Nussbaum, Private International Law 172-75 (1943). Arguably, a different law may have to be applied to the contract in cases of stipulation. Such stipulation, however, should be accorded equal recognition in contract and assignments, though only as between parties. See note 48 supra. As against third parties, the stipulation should be totally ineffective. Absent acceptance of lex loci commerciendi, courts may be expected to make the contract-assignment distinction in two cases: (1) where the court decides, for example, to use the debtor's domicile or law governing the assigned debt versions of lex situs for the assignment (these contacts have even less connection with the contract than with the assignment); and (2) where the usury laws are involved and the court, following the tendency not to find contracts other than small loans usurious, wishes to apply the law of a lenient jurisdiction. Conceivably, a flexible conflicts rule for contracts, see Nussbaum, op. cit. supra at 182, could lead to such a jurisdiction, but no established rule for assignments would do so; and thus the contract-assignment distinction would become necessary.

Even were lex loci commerciendi accepted, one aspect of the assignment arrangement would require a separate rule. Generally, it is held that the place of assignment governs the capacity to assign. Restatenent, Conflicts $\$ 351$ (1934); 3 Raber, Conflict of Laws 404 (1950). Perhaps a more persuasive argument is that "the only state with interest in capacity as such is the domicile of the person involved," except under special circumstances. Katzenbach, Conflicts on an Unruly Horse: Reciprocal Claims and Tolerances in Interstate and International Law, 65 YALE L.J. 1087, 1119 (1956); cf. Dix v. Bank of Cal. Nat'1 Ass'n, 113 F. Supp. 823 (N.D. Cal. 1952). At any rate, capacity poses no real problem in a commercial context.

The assignability of an obligation is of considerably greater importance. See, e.g., discussion of the Caristo doctrine, note 46 supra. It is ordinarily tested either by the law of the jurisdiction where the original contract was made, Dix v. Bank of Cal. Nat'l Ass'n, supra; Barbin v. Moore, 159 At1. 409 (N.H. 1932); Restatensent, Conflicts $\$ 348$ (1934); NUSSBAUM, op. cit. supra at 181, or the law governing the assigned obligation, Coleman v. American Sheet and Tin Plate Co., 285 I11. App. 542, 2 N.E.2d 349 (1936); 2 Beale, Conflict of Laws $\$ 348.2$ (1935); Dicey, Conflict of Laws 570 (6th ed. 1949); Goodrich, CONFLICT OF LAwS 341 (3d ed. 1949). The latter formulation is preferable since it permits the account debtor to conform all aspects of his contract to only one law. Yet both rules afford the debtor some predictability as to which law will determine to whom he can safely make payment. And as neither rule is linked to any event connected with the assignment, they properly recognize that the act of assigning should not change the debtor's rights. Similarly, all suits by assignees against account debtors should be ruled by the law governing the assigned contract. See 3 RABEL, op. cit. supra at 409-10. But see RestateMrent, Conflicts $\$ \$ 353-54$ (1934), recommending the place of performance of the assigned contract; accord, 2 BEALE, op. cit. supra $\$ \$ 353-54$; Ozanic v. United \$tates, 188 F.2d 228 (2d Cir. 1951); Warren v. Copelin, 45 Mass. (4 Met.) 594 (1842).

The possibility of using a separate conflicts rule for double assignments is discussed in note 78 supra. The same arguments advanced against separation of perfection and validity, see note 150 infra, apply equally against proposals to treat formal aspects of assignments differently. See Cheshire, Private Internatronal Law 258 (4th ed. 1952).

122. See note 105 supra. 
quent assignee's investigate records, ${ }^{123}$ therefore, they are more likely to search in the assignor's principal place of business than in any other jurisdiction. Moreover, unsecured creditors would receive little information of an assignor's general business health through notice of an assignment arrangement in the records of a branch state. ${ }^{124}$ Accounts receivable financing in itself may be as indicative of prosperity as of straitened conditions. ${ }^{125}$ To reveal the assignor's ability to fulfill financial obligations, inquiries would have to be effected in the home office. ${ }^{120}$

\section{Mechanics of Application \\ INSTITUTING THE RULE}

While an assignor's principal place of business can ordinarily be designated without ambiguity, unusual business structures may require a dispositive test. Executive offices are generally considered the nucleus of any concern. When, however, executive functions, accounting systems and amount of business are distributed among several states, a principal place of business may appear difficult to determine. ${ }^{127}$ The Uniform Commercial Code recommends that choice of law be geared to the location of account records; when records are maintained at several offices, internal accounting practices should be decisive. ${ }^{128}$ If the site of ledger cards is contemplated as the controlling location, this test may give rise to a branch office division of applicable law. ${ }^{129}$ Another possible explanation, however, is that the Code refers to the state in which accounts receivable files are centralized. ${ }^{\mathbf{1 3 0}}$

123. See note 106 stipra and accompanying text.

124. Such records fail to show the extent to which the company's property outside the state is encumbered.

125. See note 16 supra.

126. See note 107 supra.

127. New York Law Revision Commission, Study of Uniform Commercial Code, Article Nine 92-93 (1955). See also Uniform Commarctal Code \$ 9-103(2), concerning mobile equipment, which makes the law of the state of the borrower's chief place of business applicable. Comment 3 to $\$ 9-103$, Uniforar Commercial Code (1952 ed.), defines the chief place of business as the place "from which in fact the debtor manages the main part of his business operations. ... Although under this formula ... there will be doubtful situations, the subsection states a rule which will be simple to apply in most cases, [and] which will make it possible to dispense with much burdensome and useless filing ...."

128. The text of the Uniform Commercial Code refers merely to the office where the assignor keeps records of accounts. UNiforar Commercial Code $\$ 9-103(1)$. The comment to this section recommends that in the case of multiple records internal accounting practice-which of the various records is controlling for general accounting purposes of the enterprise-be determinative. UNIForar CoMmrerctal CODE $\S 9-103$, comment 2 (1952 ed.).

129. If the language of the comment to $\S 9-103$, see note 128 supra, is controlling, the word "record" in § 9-103(1) most likely means the ledger cards for individual accounts, which may well be kept at branch offices. But when an assignor uses accounting machines with identically punched cards and maintains duplicates at branches as well as the chief place of business, a ledger test would permit reference to the latter jurisdiction.

130. To avoid recourse to a multiplicity of state laws, courts should recognize that Uniform Commercial Code comments are not enacted by the legislature. Moreover, the 1957 version of the Code omits $\$ 1-102(3)$ (f) of the 1952 version which stated that com- 
Central accounting systems and principal executive offices are usually maintained at the same location; but when divergencies occur, the latter seems a better index of applicable law. With main executive offices determinative, assignment decisions would appropriately be confined within a legal framework fixed by the state in which company policy is directed. On the other hand, an accounting approach might be said to coincide with creditors' interests in investigating corporate prosperity. While perhaps true in the rare case of second assignees, ${ }^{131}$ unsecured creditors, who most frequently challenge assignments, ${ }^{132}$ generally lack access to company records and must direct inquiries to company personnel. ${ }^{133}$ Conversely, under a main executive office solution, public records of the headquarters state would contain accessible as well as the most complete information.

\section{Relocation}

When an assignor relocates his principal place of business, the extent of the continued applicability of the laws of the former home office state may be drawn into question. Chattel removal cases are governed by a judicially created rule generally holding perfected chattel liens valid until the lienor has notice of the displacement. ${ }^{134}$ Compliance with the laws of the new situs state within a reasonable time is then necessary for continuation of a security interest. ${ }^{135}$ This requirement reflects a compromise between protecting mortgagees

ments may be consulted in the construction and application of the act. And the word "record" in the text may be construed to mean the central accounting record.

Utilization of a records test for assignments in contrast to a chief place of business rule for mobile equipment cases, $\$ 9-103(3)$, is difficult to explain. Comment 3 situates the chief place of business at "the place where persons dealing with the debtor would normally look for credit information, . . . [which] is the appropriate place for filing." Certainly, the same rationale applies to receivables financing-perhaps even more forceably-since the problem of creditors relying on chattels at a branch operation does not arise. Nor does the records test permit more automatic application. Under both rules, as the comment admits, doubtful situations will arise. See UnIfora COMnmerclal Cone $\$ 9-103$, comment 3 (1952 ed.).

131. See note 50 supra.

132. Such challenge is made either directly or through the trustee in bankruptcy. See note 108 supra.

133. Access to company records is, of course, a question of bargaining power. While unsecured institutional lenders and powerful trade creditors may often obtain such access, the majority of trade creditors and employees apparently cannot expect the assignor to open his books to them.

134. See Restatement, Conflicts $\$ \$ 268,275$ (1934); 2 Beale, Conflict of Laws $\$ \S 268.1,268.2,275.1,275.2$ (1935) ; Goodrich, CONFLICT of LAws $\$ \$ 156-57$ (3d ed. 1949); Lee, Confict of Laws Relating to Installment Sales, 41. Mrсн. L. Rev. 445, 448-52 (1942); Note, 47 Colun. L. Rev. 767, 781-84 (1947) ; 7 WAst. \& LeE L. Rev. 45 (1950). But cf. Leary, Horse and Buggy Lien Laze and Migratory Automobiles, 96 U. PA. L. Rev. 455 (1948), disclosing that while courts purport to respect the rule preserving liens on secretly removed chattels, they often find ways to favor a local purchaser from the lienee.

135. 2 Beale, Conflict of Laws $\$ 275.2$ (1935); Uniform Conditional Sales Act $\$ 14$ (ten days after notice). Under $\$ 14$, "notice" has been construed to mean actual notice. In re Bowman, 36 F.2d 721 (2d Cir. 1929). 
against secret removal and safeguarding unsecured creditors who may see a chattel in its new location and rely on it for ultimate satisfaction..$^{136}$

In accounts receivable financing, the laws of the original state should remain applicable for the maximum maturity of commonly assigned receivables - ninety days ${ }^{137}$ _ and be relevant only to accounts assigned and existing before relocation. Since reliance concepts are not realistically germane to intangible receivables, creditors of the new state cannot object to the length of a ninety-day period, which affords assignees adequate time to conform assignments of long-term installment accounts to the laws of the new jurisdiction. Creditors in all branch office states may, however, rely on the legal relevance of either the former or new headquarters jurisdiction. Reference to either state's laws, consequently, should depend on the site of principal executive offices at the time a disputed assignment was effected. Concurrently, a ninetyday rule would protect assignees despite elimination of the notice factor. Relocation of executive offices, unlike removal of chattels, entails sufficient notoriety. ${ }^{138}$ And since responsible assignees police accounts irrespective of Benedict proscriptions, secret relocation would be virtually impossible. In fact, ninety days seems particularly well suited to commercial interests. Receivables assigned before relocation would retain the legal protection of the original state until maturity, while after-moving assignments could be easily executed in compliance with newly applicable laws.

\section{Renvoi and Transmission}

The utility of a universal conflicts rule should not be impaired, as it is the Uniform Commercial Code, by concurrent application of renvoi and transmission theories. When litigation is initiated in a code state, section 9-103(1) requires courts to consult the laws, including the conflicts rules, of the state in which an assignor keeps his records. ${ }^{139}$ While initially referring to the assignor's place of business, and perhaps to his head office in multistate oper-

136. The UnIforar Commercial Cone § 9-103(3), applicable only to chattels, recognizes the effectiveness of the old security interest for four months from the date of removal, irrespective of notice to the secured party. Some states have similar statutes with varying periods of time. Leary, supra note 134 , at $475 \&$ n.51. One of the advantages of such rules is to eliminate the problem of proving notice.

137. Note, 101 U. PA. L. REv. 392 (1952). For the average length of time of outstanding receivables in the factoring field, see Silverman, Factoring as a Financing Device, 27 Harv. Bus. Rev. 594, 605 (1949). Debts with a longer maturity may, of course, be assigned. See, c.g., N.Y. Pers. Prop. LAw $\$ 302(10)$, authorizing the assignment of retail automobile installment purchase contracts.

138. In the case of an assignment by a nonbusiness assignor of a single unmatured debt, an absolute 90-day rule may unduly burden an assignee in case of the assignor's disappearance. Two solutions are possible: (1) to toll the 90-day limit as long as the assignee exercises reasonable diligence in locating the assignor; or (2) to permit the assignee in such a situation to protect himself against subsequent assignees and unsecured creditors by notifying the account debtor.

139. Uniform Commercial Code \$ 9-103(1). 
ations, section 9-103(1) may ultimately lead back to the forum's laws-renvoi, ${ }^{14 n}$ or necessitate recourse to the laws of a third jurisdiction-transmission. ${ }^{141}$ Renvoi and transmission are generally designed to achieve, irrespective of forum, the result which would have been reached by courts in the borrower's state. ${ }^{142}$ Yet the comment to section 9-103 indicates that the code drafters were principally concerned with protecting security interests in mobile equipment. ${ }^{143}$ For example, failure of a mortgagor's state to permit recordation of liens on chattels located, and attached, in the code state would jeopardize security interests if courts in the code state could only refer to the substantive laws of the mortgagor's jurisdiction. When the conflicts rules of the mortgagor's state-presumably lex situs-are also consulted, renvoi operates to uphold those interests perfected by filing in the code jurisdiction. But since every filing statute applicable to assignments permits recordation if an assignor's principal place of business is situated in the state, ${ }^{144}$ this justification for renvoi has no application in the context of accounts receivable financing and lex loci commerciendi. Another possible explanation for the Code's employment of renvoi and transmission is that parties to chattel transactions may rely on the applicability of the situs state's laws. And with near universal acceptance of the lex situs rule, ${ }^{145}$ reference by courts in code states to the conflicts rules of a borrower's jurisdiction would complement such expectations. However, since no one doctrine enjoys general acceptance in assignment litigation. ${ }^{146}$ resorting to the conflicts rule of an assignor's state may lead to the laws of any contact jurisdiction. Should the assignor's state also countenance transmission, the laws of a fourth jurisdiction may be deemed relevant.

Instead of enhancing certainty, then, transmission would compound unpredictability in the receivables area. Furthermore, in view of existing uncertainties as to the ultimate choice of law, counsel ordinarily advise financing parties

140. For example, the state where the assignor keeps his records may adhere to a place of assignment rule and the assignment may have been made in the code-forumstate.

141. Transmission has been opposed by commentators who endorse renvoi. See, $\varepsilon . g$., Nussbaum, Private International Law 99-100 (1943).

142. Cf. Restatement, Conflicts \& \& (1934); Matter of Schneider, 198 Misc. 1017, 96 N.Y.S.2d 652 (Surr. Ct. 1950).

143. Comment 5 to $\S 9-103$, Uniform Comarercial Code (1952 ed.), is applicable to both $\S \S(1)$ and (2) of $\S 9-103$. Subsection (2) deals with the choice of law in the case of security interests in "goods of a type which are normally used in more than one jurisdiction (such as automotive equipment, rolling stock, airplanes, roadbuilding equipment $\ldots$ and the like) ...."

144. See text at notes $150-70$ infra. Ohio may be a possible exception. The statute is applicable only when the ledgers of accounts are kept in Ohio. OHIo Rev. Cone ANs. $\$ 1325.02$ (Page Supp. 1957). Should the assignor's principal place of business be located in Ohio, some ledgers would most likely be kept there. But even if ledgers were not maintained at this office, notice could be filed in Ohio since accounts are not required to exist at the time of filing ( $\$ 1325.04)$.

145. See note 58 supra.

146. See note 52 supra. 
to comply with at least the laws of the assignor's jurisdiction. ${ }^{147}$ Transmission could, therefore, combine with lex loci commerciendi to frustrate the expectations of assignment parties, and by recourse to an outmoded rule, add further precedent against an assignor's home office solution. In fact, since any precedent attained by traditional doctrine is likely to have been established in cases concerning single-debt assignments, ${ }^{148}$ adherence to renvoi and transmission in the receivables area could yield a conflicts rule which even courts in the assignor's state would not follow. ${ }^{149}$ On the other hand, upon consulting the laws of the assignor's jurisdiction, code state courts might find the conflicts precedent too questionable to activate renvoi or transmission.

\section{Statutory Implications}

In determining choice of law in multistate receivables transactions, courts may consult the recordation statutes of their own jurisdictions. Such statutes commonly dictate the effects as well as the mechanics of filing. When an assignment of accounts falls within the specific conditions of filing even though the assignor's principal place of business is not in the jurisdiction, courts may understandably be reluctant to apply lex loci commerciendi. ${ }^{150}$

147. See the article by counsel for the Mass. Bankers Ass'n, Malcolm, Conficts of Lazes, Accolnts Recciz'able, Mass. L.Q., Oct. 1945, pp. 38, 42. The author indicates that the law of the assignee's jurisdiction should also be observed. However, courts have never applied the law of the assignee's state when no other contact was found in that jurisdiction.

148. Cases involving assignments for the benefit of creditors-usually 19th centuryconstitute a substantial portion of whatever precedent is to be found in this area.

149. Outmoded precedent also presents a problem when federal courts use the conflicts rule of the state in which they sit. See note 180 infra. In both cases, the courts may feel bound by questionable precedent which has not been overturned by the state courts either because new cases have not arisen or because fact situations in new cases permitted use of old doctrines to arrive at acceptable results.

150. Courts may reason that since the legislature provided for filing in a certain county under certain circumstances, e.g., in the county where the transaction occurred if the assignor had no business or residence in the state (Iowa), it must intend the law of the state to apply to the validity as well as the perfection of assignments. The term perfection usually embraces such formalities as recording, acknowledgment, etc. Under validation statutes, perfection would simply entail the act of assignment; in English rule statesnotification of account debtors; in recordation states-filing of notice; and in North Dakota -marking of the assignor's books. Validity, in this context, may be viewed as the protection afforded an assignee as against all other parties, by virtue of perfection. Arguably, perfection and validity may be distinguished, and the conflicts implications of recording requirements confined to the former. While such a distinction would permit courts to determine validity by the lcx loci commerciendi rule, it represents a poor compromise between multiple and single state law compliance. Besides placing on the assignee the burden of filing, notifying and bookmarking in a great many states without in fact appreciably increasing protection to creditors, see notes 121-26 supra and accompanying text, the perfection-validity distinction is open to other objections. Accounts receivable statutes principally vary: (1) in the effect which they give to notification or filing as against other assignees or creditors, in good faith or not, prior or subsequent; (2) in the applicability of the statute to different kinds of accounts; and (3) in their acceptance or rejection of Benedict v. Ratner and the assignability of after-acquired accounts. See notes $32-46$ supra. 
Most recordation statutes, however, permit judicial application of the lc. ${ }^{*}$ loci commerciendi rule. Of the twenty-three statutes, ${ }^{151}$ five merely provide that notice of assignments shall be filed with the secretary of state. ${ }^{152}$ This absence of legislative specificity allows courts discretion in selecting the conditions under which the laws of their state apply. Three other statutes also provide for filing with the secretary of state but only when the assignor's principal executive offices are in the jurisdiction. ${ }^{153}$ In these states, lex loci commerciendi can be considered affirmatively suggested for choosing applicable law in multistate assignment cases.

Further support for lex loci commerciendi may be derived, in some cases, from the Uniform Commercial Code, ${ }^{154}$ enacted in two states, ${ }^{155}$ and from the Ohio statute. These acts provide that the laws of the state, including filing requirements, shall govern if ledgers-Ohio, or records-UCC, of accounts are maintained in the jurisdiction. Thus, both embody lex loci commercicndi when the assignor's business is not divided into branches. Moreover, Ohio courts, when presented with branch office assignment cases in which ledgers are not kept in the state, could find basis in the statute's negative implications for referring to the state in which account records are centralized. ${ }^{156}$ By making its laws applicable only when ledgers are situated in the state, the Ohio legislature can be said to have recognized the predominant significance of this contact point and the superior interest of a foreign jurisdiction when the contact occurs elsewhere. Accordingly, in a single-state business situation, Ohio courts could hold the laws of the assignor's state controlling. And because of the undesirability of applying divergent laws of several states, central accounting should dictate choice of law when assignors operate multistate branches..$^{157}$

Filing alone, in a given state, seems meaningless except in so far as it protects against certain classes of people and sanctions certain practices. For the purpose of a statute is certainly not implemented by giving its filing provisions a different effect from that contemplated by the legislature. Perfection divorced from validity appears an empty gesture. On the other hand, including the above items within a perfection definition would virtually remove the attempted distinction. Thus, courts are not likely-perhaps properly-to escape conflicts implications derived from these statutes through use of a perfection-validity distinction.

151. See note 33 supra, listing the twenty-two filing statutes plus the Michigan statute, which, though basically a validation statute, has filing requirements for certain circumstances.

152. Ariz., Idaho, Mo., Utah, Wash. Idaho has a separate statute codifying, in effect, the rule of the assignor's state. See note 173 infra.

153. Colo., Fla., Kan. The exact terminology varies slightly: "principal business office in the United States" (Colo.); "main executive office in the United States" (Fla., Kan.).

154. UNIFORM COMMIERCTAL CODE § 9-103(1).

155. Massachusetts and Pennsylvania. See note 33 supra.

156. OHro Rev. Cone Ann. $\$ 1325.03$ (Page Supp. 1957), provides that notice shall be filed in the county of the assignor's principal place of business in Ohio, or, if he has none, where ledger sheets for the particular account are maintained. Section 1325.02 makes the statute applicable only if the ledger sheet of the assigned account is maintained in Ohio.

157. Perhaps further support for this proposition may be derived from the statute's reference to principal place of business in Ohio. See note 156 supra. 
While the location of central accounting and main executive offices will sometimes differ, ${ }^{158}$ the solution appears more practicable than a branch office division of applicable law. ${ }^{159}$ Reference to other states where records are maintained, only negatively implied by the Ohio statute, is specifically required by the $U C C$. Furthermore, should account records be kept at a branch office in a UCC state, courts could impose a central accounting interpretation on the code provision and view the assignor's state law as decisive. ${ }^{160}$ Unfortunately, Ohio courts would be forced to apply the laws of the forum whenever ledger cards were maintained at a branch in the state; statutory amendment may therefore be indicated.

Eight other statutes support application of lex loci commerciendi in singlestate business cases. These statutes require notice of assignments to be filed in the county of the assignor's principal place of business, ${ }^{161}$ five adding the county of his residence if business offices are not situated in the state. ${ }^{162}$ That this type of statute is not intended to apply when assignors have neither business nor residence in the state has already been decided. ${ }^{163}$ That the foreign jurisdiction containing the assignor's principal place of business should be

158. See text at notes $127-33$ supra.

159. The branch office problem is discussed at notes 108-26 supra and accompanying text.

160. See notes 127-30 supra and accompanying text. Renvoi and transmission, of course, might pose obstacles. See text at notes $139-41$ supra.

161. Ala., Cal., Ga., La., Mich., N.C., S.C., Vt. For variations in the language of these statutes, see notes $162,164,165$ infra. For discussion of a California statute which seems to require reference to the assignor's state, see note 173 infra.

162. Cal. Georgia requires filing in the county of the assignor's principal place of business if the assignor is a corporation, a partnership or a nonresident individual; if a resident individual - the county of residence. The Michigan, North Carolina and South Carolina statutes are very similar. The Iowa, Nebraska, Oklahoma and Texas statutes, which also refer to the assignor's residence, are discussed separately in notes 168-70 infra and accompanying text.

163. In Smith v. Harris, 127 Cal. App. 2d 311, 273 P.2d 835 (1954), one of the rare cases arising under the new statutes and involving conflicts questions, a Texas borrower assigned accounts receivable, including a California account, to a New York lender who filed in Texas but not in California. A creditor of the assignor then tried to attach the debt in California. The court held that while the place of assignment (New York) controlled "formal validity," the law of the account debtor's domicile (California) governed the necessity of notice, of recording or of taking possession in order to uphold the assignment against third parties. However, since the assignor had neither place of business nor residence in California, the court found the California statute inapplicable, adding that, in the normal course of commercial transactions, credit responsibility is best ascertained at the assignor's place of business or residence (Texas). The court then held the assignment good under California common law and incidentally indicated its validity under New York law and, because of filing, under Texas law. Having correctly pronounced the California statute inapplicable and recognized that creditors should look to Texas records for information, the court should have taken the logical step of holding Texas law controlling. Reversion to common law, which the statute was clearly designed to supersede, was contrary to legislative intent. Moreover, the court ignored the availability of a California statute requiring reference to the law of the assignor's state. See note 173 infra. 
consulted may be implied by the significance imported to this contact point by the state legislatures. While language in three of the statutes would permit courts to refer to the laws of the assignor's principal place of business when branch offices are located in the forum, ${ }^{164}$ other statutes in the group militate against this result. ${ }^{165}$ And most suggest application of the forum's laws when assignors reside in the jurisdiction. ${ }^{166}$ Since accounts receivable financing is normally conducted by corporations, the residence proviso should not unduly constrict utilization of lex loci commerciendi. ${ }^{\mathbf{1 0 7}}$ Branch office qualifications, on the other hand, may constitute an obstacle which can only be remedied by statutory amendment.

Legislation in four states may preclude adherence to the lex loci commerciendi rule. The Oklahoma and Texas statutes provide for recordation at the state capital if assignors have neither residence nor office within the state. ${ }^{10 \mathrm{~s}}$ Similarly, the Nebraska statute requires recording in the account debtor's

164. The Georgia, Michigan and Vermont statutes require filing in the county (or town) of the assignor's principal place of business. Since any firm is considered to have only one principal place of business, the statutes of these states may be reasonably construed as inapplicable when the principal place of business is elsewhere. Indeed, the Georgia statute supports such an interpretation. For the definition of the phrase "principal office," it refers to $\$ 92-2405$ which indicates that one office wherever located-not principal office within Georgia-is contemplated.

165. The Alabama and California statutes refer to the assignor's place of business in the state. The Alabama statute, however, merely states that any person "is entitled to file" in the county referred to, while California states an assignment to be void unless so filed. Alabama thus leaves room for an interpretation holding filing permissive when only a branch office is located in the state.

The Louisiana statute requires filing in the parish in which the assignor's place of business is located and specifies that each separate establishment at which business is conducted is to be regarded as a separate place of business. Not only must the assignee file in Louisiana if the assignor has a branch there, he must file in each parish in which a branch is located. The same result obtains under the North and South Carolina statutes which specify that notice is to be filed in "any county wherein the assignor has a place of business." Worse, if the assignor is a domestic or domesticated corporation, filing is also necessary at its statutory principal place of business. If an assignor is incorporated in one of these states but does no business there, filing will nevertheless be required.

The North Carolina statutes elsewhere provide that an account shall be deemed located in that state: "(a) If the transaction out of which the account arose occurred in this State, or if payment is to be made in this State, or (b) If the account has been transferred to this State so that the place of payment of the account is in this State, or (c) In all other cases where an account is deemed located in this State under general rules of law." No reference to the significance of such location may be found in the statute. Yet a court might interpret the provision to imply a lex situs rule. See text at notes $58-73$ supra, notes $168-70$ infra. But since the filing requirements are a more likely (and relatively more sensible) indication of legislative intent on conflicts questions, this provision should be viewed as designed only for tax, inheritance and bankruptcy purposes. See note 179 infra.

166. See note 162 supra.

167. The statutes referring to residence, note 162 supra, pertain to individuals only, and not to the legal domicile of corporations. When a nonincorporated businessman lives in one of the five states listed, but conducts his business in another state, compliance with the laws of both states will be necessary.

168. The Hawaii statute is similar in that it requires the filing statement to designate 
county of business or residence when assignors have no contact with the state. ${ }^{160}$ Absent remedial legislation, multistate receivables may be vulnerable to effective garnishment in these states unless the filing requirements of the forum are fulfilled. Again, Iowa's statute appears to prevent a lex loci commerciendi solution by providing for recordation in the county where the transaction creating the account occurred if the assignor has no residence or office in the jurisdiction. To the extent courts consider such provisions dispositive on choice of law, amendment will be prerequisite to universal acceptance of lex loci commerciendi. ${ }^{170}$

\section{Judicial Precedent}

In jurisdictions where lex loci commerciendi is not obstructed by statute, obsolete precedent can be justifiably overturned. Conflicts issues have arisen principally in cases testing the assignment of individual debts. ${ }^{171}$ Future litigation, however, is likely to involve the expanding institution of multistate accounts receivable financing. Within this broadened framework, traditional rules would be as impracticable for courts to apply as they are for parties to follow. One outgrowth of the uncertainty caused by single-debt precedent is that counsel advise financing parties to comply with at least the laws of the assignor's jurisdiction. ${ }^{172}$ Accordingly, departure from outmoded conflicts rules would not thwart commercial expectations. A further consequence appears in the regularity with which courts select the laws of the assignor's state

the assignor's chief place of business elsewhere whenever the assignor has no place of business in the territory.

Conceivably, courts wishing to use lex loci commerciendi could interpret these clauses as providing for voluntary rather than mandatory filing whenever the assignor has neither residence nor office in the state. In view of the commercially senseless and destructive nature of multiple filing requirements, this construction does not seem unrealistic, especially since precedent for voluntary filing exists. Thus, UNIForM COMMERCIAL CODE \$ 9-103(2) provides for permissive filing where filing is not allowed in the state of the assignor's chief place of business. Even if this interpretation is accepted, the statutes of these states would still have to be applied if a branch office is located in the state, for both statutes refer to the assignor's principal office within the state and thus fall into the group of statutes listed in note 165 supra.

169. If the assignor is a nonresident and has no place of business within the state, notice shall be filed in the county of the account debtor's residence or at his principal place of business in the state.

170. Should the courts consider these statutes dispositive on choice of law, the multiplicity failing of traditional doctrines would be compounded in that the conflicts rules in any state would vary with the nature of the contacts involved. In Nebraska, the rule would seem to be lex sitis (i.e., the account debtor's residence) as long as the assignor had no office in the state, but a branch office version of lex loci commerciendi when the assignor had such an office. In Iowa, the shift to such a version of lex loci commerciendi would be from a place of assignment rule, in Oklahoma and Texas, from either lex situs or place of assignment. These difficulties suggest that a permissive filing interpretation, however tenuous it may be, is preferable, see note 168 supra; for such interpretation would at least yield a commercially sensible result.

171. Moreover, all the major treatises on conflict of laws seem concerned solely with transfers of individual debts.

172. See note 147 supra and accompanying text. 
under variant constructions of traditional doctrines. ${ }^{173}$ Ratification of lex loci commerciendi would, therefore, represent more of a deviation in rationale than in effect. Just as the business community has recognized that the utility of receivables security transcends the assignment of a single debt, courts should openly acknowledge that the conflicts problems in modern usage exceed the aim and capacity of older doctrine.

In bankruptcy litigation, lex loci commerciendi can be established as part of the federal common law. Pursuant to the Supreme Court decision in Klaxon Co. v. Stentor Co., ${ }^{174}$ federal courts hearing assignment cases on diversity jurisdiction must apply the conflicts rules of the state. ${ }^{175}$ The validity

173. A survey of case law shows that, while a place of assignment rule is most often enunciated, the assignor's place of business or residence is ordinarily located in the same jurisdiction as the place of assignment. Among cases in which these two contacts occur in different jurisdictions, more courts choose the assignor's jurisdiction (under various doctrines) than that of the assignment. The account debtor's, and even more so the assignee's, location, are contacts often found outside of the jurisdiction whose law is chosen. Localizing other contact points, such as performance of the assigned obligation, performance of the assignment, etc., is too difficult, from the report of many cases, to present comparison.

Frequently, courts fail to isolate one selected rule, especially when many contact points cumulate in the applicable jurisdiction, and merely list all the conflicts rules occasioning the same result. See, e.g., Union Trust Co. v. Bulkeley, 150 Fed. 510, 517 (6th Cir. 1907); Wishnick v. Preserves \& Honey, Inc., 153 Misc. 596, 275 N.Y. Supp. 420 (Sup. Ct. 1934). Even when a single rule is chosen, the court may well be willing to use a traditional doctrine uncritically as long as a satisfactory result is obtainable. Some cases have different meanings for different critics-each reading the case to support his rule. Compare, e.g., the treatment of Lewis v. Bush, 30 Minn. 244, 15 N.W. 113 (18S3), in 2 BEALE, Conflict of Laws $\$ 354.1$ (1.935) ; 3 Rabel, Conflict of Laws 425 (1950); Stumberg, Conflict of LAws 262 (1951); Flanagan, Assignments of Acconnts Receivable and the Conflict of Lazes Under the Bankruptcy Act, 2 VAND. L. Rev. 409, 417 (1949).

Lex loci commerciendi often coincides with the rule of the place of performance of the assigned contract. For payment of accounts usually occurs at the assignor's place of business. Flanagan, supra at 422 . Additional support for lex loci commerciendi may be derived from another traditional doctrine. Mobilia sequuntur personam holds that the law of the place where the transferor of personal property is located governs the transfer of such property. Once widely followed in the case of chattel transfers, the rule has been largely abandoned in favor of lex situs. See Lalive, The Transfer of Chattels in the Conflict of Laws $34-43$ (1955) ; Zaphiriou, The Transfer of Chattels in Private International Law 17-24 (1956). Yet four states have codified the doctrine: "If there is no law to the contrary, in the place where personal property is situated, it is deemed to follow the person of its owner, and is governed by the law of his domicile." CaL. Civ. Code \$ 946; Idaho Code Ann. \$ 55-401 (Supp. 1957) ; Mont. Rev. CoDes ANv. \$ 67-1101 (Supp. 1957) ; N.D. Rev. CoDe $\$ 47-0701$ (1943). While this statute has not been applied to commercial financing, it has been used in intangible cases. Fenton v. Edwards \& Johnson, 126 Cal. 43, 58 Pac. 320 (1899) ; Bruton v. Villoria, 138 Cal. App. $2 \mathrm{~d} 642,292$ P.2d 638 (1956). Thus, the statutes may be viewed as codifying lex loci commerciendi, especially since the assignor's domicile may give way to a "business situs." Miller v. McColgan, 17 Cal. 2d 432, 110 P.2d 419 (1941). But see Smith v. Harris, 127 Cal. App. 2d 311, 273 P.2d 835 (1954), note 163 supra.

174. Klaxon Co. v. Stentor Elec. Mfg. Co., 313 U.S. 487 (1941).

175. The Klaxon case is too unequivocal and too firmly established to permit hope for 
of accounts receivable security, however, is most frequently litigated before federal courts invoking bankruptcy jurisdiction. ${ }^{176}$ While the Supreme Court has declined to rule whether Klaxon pertains to nondiversity suits, ${ }^{177}$ two circuit courts have considered it inapplicable when jurisdiction is derived from the Bankruptcy Act. ${ }^{178}$ Moreover, Klaxon is criticized generally as facilitating the very forum shopping that Erie sought to eliminate, ${ }^{179}$ and specifically

any deviation from its holding short of legislative action. See Annot., 21 A.L.R.2d 247, 251-56 (1952).

176. See, e.g., In re Rosen, 157 F.2d 997 (3d Cir. 1946) ; Zydney v. New York Credit Men's Ass'n, 113 F.2d 986 (2d Cir. 1940).

177. McKenzie v. Irving Trust Co., 323 U.S. 365, 371 n.2 (1945); D'Oench, Duhme $\&$ Co. v. Federal Deposit Ins. Corp., 315 U.S. 447, 456 (1942).

178. In In re Rosen, 157 F.2d 997, 999 (3d Cir. 1946), cert. denied, 330 U.S. 835 (1947), Judge Goodrich stated his belief that a bankruptcy court is not bound by state rules of conflicts. Yet he did not decide the point, presumably since state and federal law coincided in that case. Similarly, in In re American Fuel \& Power Co., 151 F.2d 470, 475 (6th Cir. 1945), aff'd on other grounds sub nom. Vanston Bondholders Protective Comm. v. Green, 329 U.S. 156 (1946), the Sixth Circuit emphasized that Klaxon may not apply in bankruptcy litigation, but again the question did not have to be decided. See also De Sylva v. Ballentine, 351 U.S. 570 (1956), where, after holding that the meaning of a term should be determined by state law, the Court implied that it was free to determine applicable state law.

Incorporation of conflicts rules into bankruptcy law is proposed by numerous commentators. Hart \& Wechsler, The Federal Courts and the Federal Systear 635-36

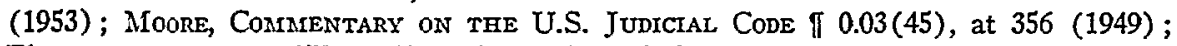
Flanagan, supra note 173, at 413; Hart, The Relations Between State and Federal Law, 54 ColuMr. L. Rev. 489, 513-14 (1954); Mishkin, The Varionsuess of "Federal Law": Competence and Discretion in the Choice of National and State Rules for Decision, 105 U. PA. L. KEv. 797, 806-08 (1957).

179. Clark, C.J., in Collins v. American Automobile Ins. Co., 230 F.2d 416, 419-20 (2d Cir. 1956).

With Klaxon applicable in bankruptcy, federal courts would have to employ the divergent conflicts rules obtaining in state jurisdictions. Thus, "shopping" for certain federal courts could benefit assignees or trustees in bankruptcy. Forum shopping in bankruptcy is possible to the extent that parties may choose between summary and plenary jurisdiction. Assignees deemed in possession of accounts may either force the trustee to bring plenary proceedings or voluntarily submit to summary action in the bankruptcy court. The trustee cannot object to such voluntary submission. 2 ColliER, BANkRUPTCX $\llbracket 23.08$ [5] (14th ed. 1956). The right to insist on a plenary action may be lost by filing a claim against the bankrupt estate for the deficiency between the debt owed by the bankrupt and the collateral securing it. For the assignee may be held to have thereby consented to a summary adjudication of the assignment's validity unless he expressly reserved the right to a plenary action. 2 id. If 23.08[6]; 4 id. \ 68.20; Kupfer, Accounts Receivable Financing: A Legal and Practical Look-See (Part 2), The Practical Lawyer, Dec. 1956, pp. 55, 56. Whenever property which the trustee attempts to recover is in actual or constructive possession of the bankruptcy court, the trustee may proceed summarily in that court. 2 CoLLIER, BANKRuPTCY If 23.05[1] (14th ed. 1956). The question whether or not an assigned chose in action is in the bankruptcy court's constructive possession has been the subject of much litigation, with the courts arriving at divergent results. 2 id. $\Uparrow 23.05$ [4] nn.24 \& 25. Attempting to reconcile these cases, one commentator suggests that "where there has been an outright and complete assignment of the chose in action..., as distinguished from a mere encumbrance of it, a summary proceeding will not lie, and a plenary suit is the proper remedy." 2 id. \23.05[4]. Accordingly, recourse arrangements would come under sum- 
in bankruptcy as frustrating the uniformity objectives of the act. ${ }^{180}$ When, as

mary jurisdiction while nonrecourse arrangements would necessitate plenary suits. But the cases cited seemingly do not fully support this contention. In $r e$ I. Greenbaum \& Sons Co., 6 F. Supp. 245 (S.D.N.Y. 1933), and In re Paramount Fireproof Door Co., 43 F.2d 558 (E.D.N.Y. 1930), are illustrative. Accounts were assigned as security for loans, yet the courts held the assignees to be in possession so as to require plenary actions. In the Greenbanm case, the court noted that lack of possession in the assignee was evidenced by the assignor's continued collection of accounts and failure to notify account debtors. In the court's view, this consideration was outweighed, however, by the assignor's delivery of ledger sheets and memoranda, as well as his compliance with the requirements of Benedict v. Ratner. See note 17 supra. Cases holding that the trustee had constructive possession involve either (1) partial assignments, in which case the courts reason that the partial title remaining with the bankrupt justifies summary proceeding, Schwartz v. Horowitz, 131 F.2d 506 (2d Cir. 1942); In re Lafayette Agency, Inc., 43 F. Supp. 330 (S.D.N.Y. 1942); or (2) nonnotification financing arrangements in which the parties violated Bcnedict $\approx$. Ratner, In re Prince, 89 F.2d 681 (2d Cir. 1937) ; In re Borok, 50 F.2d 75 (2d Cir. 1931): In re Capitaine, 31 F. Supp. 312 (E.D.N.Y. 1940) ; cf. Street v. Pacific Indemnity Co., 61 F.2d 106 (9th Cir. 1932). The question remains as to the course of judicial action in cases of financing arrangements not meeting Benedict requirements in jurisdictions not following the Benedict rule. In any event, in ordinary receivables arrangements, assignees may refuse to submit to summary jurisdiction.

When the assignee does not voluntarily submit to summary jurisdiction, the trustee may bring a plenary suit in any court, state or federal, in which the bankrupt might have initiated an action. Bankruptcy Act $\$ 23,52$ STAт. $\$ 54$ (1938), 11 U.S.C. $\$ 46$ (1952). If the trustee proceeds under $\S \S 60,67$ or $70(\mathrm{e})$, he may bring the action in a federal court. whether or not the bankrupt could have done so. Bankruptcy Act $\$ \$ 60(\mathrm{~b}), 67(\mathrm{e}), 70(\mathrm{e})$ (3), 52 Stat. 870, 878, 882 (1938), 11 U.S.C. $\$ \S 96(\mathrm{~b}), 107(\mathrm{e}), 110(\mathrm{e})(3)$ (1952). Of the sections used to invalidate transfers, only the "strong-arm clause," $\$ 70(\mathrm{c}), 66$ STat. 430,11 U.S.C. $\$ 110$ (c) (1952), confines the trustee to state courts when the bankrupt would have been so limited. The trustee's plenary action may be brought in the jurisdiction of the assignee's residence, anywhere the assignee may properly be served with process or in the jurisdiction where the property is located. 2 Collier, Bankruptcr $\llbracket 23.15$ [1] (14th ed. 1956). When intangibles are involved, the trustee may try to establish situs at any one of the places enumerated in the text at notes 60-65 supra. See also Andrews, Situs of Intangibles in Suits Against Nonresident Claimants, 49 YALE L.J. 241, 254-61 (1939). A wide choice of jurisdictions may consequently be available. Possibly, the assignee could initiate a prior action against the trustee in a district court under 28 U.S.C. $\$ 1655$ (1952), to remove a "cloud upon the title to . . . personal property within the dis-" trict." In Lockhart v. Mercer Tube \& Mfg. Co., 53 F. Supp. 301 (D. Del. 1943), a transferee had obtained a default judgment clearing title to shares which the trustee had claimed were fraudulently transferred. The court held that the default judgment was res judicata against the trustee; it emphasized that the trustee's charge of fraudulent transfer had so clouded the title to the shares as to impair their marketability. Whether analogous reasoning could be applied to a lien on receivables is uncertain, especially since courts split on whether "personal property" within the meaning of the statute includes simple debts. Annot., 30 A.L.R.2d 208, 251-53 (1953). See, generally, Blume, Actions Quasi In Rcm Under Section 1655, Title 28, U.S.C., 50 MrCH. L. Rev. 1 (1951).

The bankruptcy court, of course, may sit in the jurisdiction where the bankrupt has his principal place of business, his residence or his domicile. Bankruptcy Act $\$ 2$ (a) (1), 52 STAT. $\$ 42$ (1938), 11 U.S.C. $\$ 11$ (a) (1) (1952). But the choice among these jurisdictions is not within the power of either the trustee or the assignee, unless the latter himself brought the petition in bankruptcy.

180. See, generally, cases cited note 178 supra. By referring to state law, the Bank- 
in assignment cases, state conflicts rules generate jurisdictional accidents, a federal rule of conflicts seems particularly desirable. Indeed, federal court establishment of lex loci commerciendi would complement bankruptcy policy. Through incorporation of state laws, the Bankruptcy Act recognizes state interest in determining the conditions under which borrowers may place property beyond the reach of general creditors. As a rule, lex loci commerciendi would recognize the interests of the state most concerned with balancing the conflicting claims of the bankrupt and his creditors. ${ }^{181}$

ruptcy Act recognizes the desirability of not adding, as far as possible, further rules to those with which a lender must comply in order to protect his security interest. This objective is not inconsistent with the act's overall purpose of settling bankruptcy problems in a uniform and orderly manner, irrespective of where litigation is brought. Through using state conflicts rules, however, the courts would reduce uniformity without lessening the requirements to which a security arrangement is subject. On the use of state rules of conflicts, see Note, $68 \mathrm{H}_{\mathrm{ARV}}$. L. REv. 1212, 1218-22 (1955).

Federal use of state laws of conflicts may be made more undesirable by the assumption that federal courts cannot reappraise the validity of a case in point decided by a state court of last instance, no matter how old the precedent or how out of time its doctrine. See Rehm v. Interstate Motor Freight System, 133 F.2d 154 (6th Cir. 1943) ; Boston Cas. Co. v. Bath Iron Works Corp., 136 F.2d 31 (1st Cir. 1943). The rule has been extended to apply to decisions by intermediate appellate state courts, unless the federal court is "convinced by other persuasive data that the highest court of the state would decide otherwise." West v. American Tel. and Tel. Co., 311 U.S. 223, 237 (1940) ; Fidelity Union Trust Co. v. Field, 311 U.S. 169 (1940) ; Gettins v. United States Life Ins. Co., 221 F.2d 782, 785 (6th Cir. 1955) ("it is not for us to exercise our independent judgment, to look to other jurisdictions, or to speculate as to what the Supreme Court of Ohio might some day decide"). Much criticism has been aimed at the rule. Broh-Kahn, Uniformity Run Riot-Extensions of the Eric Case, 31 Kx. L.J. 99, $101-07$ (1943) ; Clark, State Law in Federal Courts: The Brooding Omipresence of Erie v. Tompkins, 55 YALE L.J. 267, 290-94 (1946); Keeffe, Gilhooley, Bailey \& Day, Weary Erie, 34 CoRner L L.Q. 494, 514-20 (1949). While a litigant would have the opportunity to persuade a lower state court not to follow another lower court decision-one not being bound by the other-the same litigant would be deprived of this opportunity in a federal court. Certain federal courts, therefore, have invented fine distinctions whereby they are permitted to use their own judgment. Id. at 517-19.

In the recent case of Bernhardt v. Polygraphic Co., 350 U.S. 198 (1956), the Supreme Court seemed to suggest "that a state decision may be rejected if the decision itself or other decisions on the same subject contain ambiguities or inconsistency of reasoning, or if it is overshadowed by the logic of more recent authorities." 45 CALIF. L. REv. 87, 89 (1957). Mr. Justice Frankfurter, concurring, asserted that out-of-state authorities should be used and that consideration should be given to the fact that the state's highest court has not been too hesitant in overruling itself. Bernhardt v. Polygraphic Co., supra at 205-12. Such an attitude should do much to help federal courts unwilling to adopt federal conflicts rules reach reasonable results in receivables financing cases even when they confront strong traditional precedent in state courts. See also note 148 supra.

181. Application of a federal conflicts rule in bankruptcy, however, appears problematical in view of the strong tendency of lower federal courts to apply state conflicts rules in other nondiversity cases. See, e.g., United States v. Henke Constr. Co., 157 F.2d 13, 23-24 (Sth Cir. 1946) (action brought under Miller Act, but court emphasized fact that suit was in nature of action on contract and did not involve construction of federal statute) ; Sprague Elec. Co. v. Cornell-Dubilier Elec. Corp., 62 F. Supp. 1 (D. Del. 1945) ; In $r e$ Wisconsin Cent. Ry., 63 F. Supp. 151 (D. Minn. 1945); Gonzales v. Tuttman, 59 F. Supp. 858 (S.D.N.Y. 1945). 


\section{Conflicts Prevention}

Risks inherent in prevailing conflicts rules can be diminished by financing parties. While courts are unlikely to accept lex loci commerciendi within the near future, parties themselves can counteract unpredictable choice of law by decreasing the number of relevant jurisdictions. Careful planning simply entails concentrating most significant events in one jurisdiction so that selection of law will not appreciably vary despite the conflicts rule eventually employed.

More specifically, governing contracts should be executed in the assignor's jurisdiction with stipulations for the laws of that state to apply. ${ }^{182}$ All accounts arising at branches should then be sent to the head office before delivery to the assignee. With such precautions, the majority conflicts rule-place of assignment — can be harnessed to the laws of the assignor's state. Similarly, all aspects of performance should be effected in the assignor's jurisdiction. The assignee can designate an agent in the state to regulate credit ratios and to accept or reject receivables for assignment. Proceeds collected at branches should first be transmitted to headquarters and then placed in a local banl: which should also manage credit advances. When feasible, accounts should be made directly payable at the home office. If financing is conducted in notification form, account debtors should be directed to remit payments to the assignee's bank or agent in the assignor's state. Accordingly, choice of law under place of performance or center of gravity would not depart from a lex loci commerciendi solution. ${ }^{183}$

Remaining contact points-the assignee's and account debtors' business locations-create absorbable risks. Absent further contacts at the assignee's place of business, the laws of his state have never been chosen to govern assignment transactions. On the other hand, with the situs of debts following account debtors, ${ }^{184}$ and lex situs supported by precedent or implied by statute, ${ }^{185}$ the laws of account debtors' states are possible selections. ${ }^{186}$ Garnishment actions, particularly those brought by resident creditors, may engender judicial pre-

182. Each schedule should contain such a stipulation. This, in most jurisdictions, would be sufficient to insure application of lex loci commerciendi in litigation between the parties. See Note, 62 HARv. L. REv. 647 (1949). Courts, however, may reject stipulations used to escape recording requirements. Id. at $654 \mathrm{n} .67$. The avoidance of small print in the contract may be important to acceptance of the stipulation. Id. at 656. See also Annot., 112 A.L.R. 124 (1938).

183. To avoid difficulties with the Uniform Commercial Code or the Ohio statute, see notes 154-60 supra and accompanying text, the assignor should keep his ledger sheets at the principal place of business when commercially feasible.

184. See notes 63,64 supra.

185. See notes $58-73$ supra and accompanying text; notes $168-70$ supra and accompanying text.

186. Most disturbing, in this connection, is not the possible loss of a few accounts whose debtors are located in a state in which the assignee failed to perfect the assignment, but the "part bad, all bad" rule of Brown v. Leo, 12 F.2d 350 (2d Cir. 1926). There, a mortgage covering real estate, chattels and fixtures was held entirely invalid because the chattel security was bad under the rule of Benedict a. Ratner. See also Moore v. Bay, 284 U.S. 4 (1931) (although lien is good against all but creditors who became such prior 
dilections for the laws of the forum. ${ }^{187}$ Bankruptcy suits, however, should not pose the lex situs problem. In such proceedings, whether summary or plenary, the validity of the entire accounts receivable arrangement must usually be determined. And the difficulty of interpreting laws in every state in which account debtors may be found, as well as the problem of devising fair methods of apportioning proceeds, ${ }^{188}$ makes lex situs an unlikely choice. Thus reduced, conflicts risks may be subsumed by margins between the amount of credit extended and the face value of accounts assigned. Nevertheless, the uncertainties caused by prevailing doctrines cannot be eliminated, nor sound prediction of the validity of less propitiously planned financings approached, until lex loci commerciendi is universally adopted.

to recordation, the trustee can invalidate the whole security). But see In the Matter of Cable-Link Corp., 135 F. Supp. 277 (E.D. Mich. 1955) (Moore v. Bay doctrine not applicable where there is no existing creditor).

187. See note 70 supra. This tendency appears most strongly where a forum state creditor attaches a debt in that state which had been assigned in another state. Some courts have been very open in stating that a different rule will be used whenever a domestic creditor is involved. See, e.g., Woodward v. Brooks, 128 I11. 222, 20 N.E. 685 (1889).

18S. See notes 109-10 supra and accompanying text. 